\title{
4 Nietzsche's psychology of religion in Human, All Too Human and Daybreak
}

This chapter is devoted to examining Nietzsche's psychological approach to religion in $H H$ and $D$.

Although this involves clarification and reconstruction, the aim of the chapter is not primarily to present a summary of Nietzsche's views. A mere systematizing summary would run the risk of depriving the reader of a sense for the rich affective dimension of Nietzsche's text, which is precisely what concerns us. So besides presenting Nietzsche's thinking about the topic on the basis of the content of the works (sections 4.1 and 4.3), this chapter also explores what can be said about Nietzsche's use of mood in these two works and to what extent that should influence the interpretation of his remarks on religion (sections 4.2 and 4.4). These latter questions are pursued through a critical engagement with the work of Jacob Golomb (on $H H$ ) and Rebecca Bamford (on $D$ ). Many scholars have made scattered, cursory remarks about Nietzsche's use of affective means in his writings, but these two are the only scholars who have paid serious attention to Nietzsche's use of mood in these specific works. If indeed mood is central to the conception of these early works, there is reason to assume that it is of no small importance to examine its role thoroughly. The question of mood is worth more than a footnote or two, if one aims for a viable reading.

\subsection{Schopenhauer's shadow and the independence of $H H$}

The following foray into Human, All Too Human serves to outline the basics of Nietzsche's psychological approach to religion. The focus of the reading will be on questions of affectivity, which means I will necessarily ignore most of the work. The chosen approach is justified within the context of the work at hand as the chapter is meant to perform a preliminary function. This function consists in outlining the basics of Nietzsche's psychological approach to religion, before we move on to $D$ and $G S$. Besides this pragmatic justification, there are more important reasons for the focus on affectivity. I will argue that the focus on affectivity improves our understanding of Nietzsche's departure from Schopenhauer's philosophy of religion. That matters because it is after all precisely this departure, which allows one to consider $H H$ foundational for Nietzsche's development into an independent thinker. The focus on affectivity makes it possible to argue against the popular narrative which holds that as Nietzsche in $H H$ distances himself from Schopenhauer's philosophy, he also seeks a perspective that renounces all ideals and denies the value of feelings. ${ }^{1}$ If one would fully embrace that view, it would hardly make sense to speak

1 E.g. Marco Brusotti contends that Nietzsche in $H H$ seeks a perspective that is not only free from 
of Nietzsche giving any significant constructive role to feeling in that work, not to speak of him making use of mood. Therefore, I will begin by challenging that narrative, whereafter I will through an examination of the foundations of Nietzsche's psychological criticism move on to the question about the potential constructive role of mood in the work (section 4.2).

\subsubsection{A turn against feeling?}

What makes the narrative that Nietzsche turns against all feeling so compelling is that it not only superficially fits what we know about the circumstances which led to the creation of $\mathrm{HH}$ but that Nietzsche himself also suggests the possibility of such an interpretation. In his late work, Ecce Homo, Nietzsche recounts that it was his sobering experience of the first Bayreuth Festival of 1876 that triggered the crisis that found its expression in $H H$ (KSA 6, 323-324; cf. Young 2010, 224 and Franco $2011,10)$. That the crisis was a matter of feeling and taste, more specifically a rejection of that which he encountered at the festival, is beyond doubt. Was it also a rejection of feeling more generally? The terse aphoristic style as well as the philosophical content of $\mathrm{HH}$, especially its piercing psychological analyses of feelings, might tempt one to affirm that conclusion. In contrast to the baroque excesses of feeling displayed at Bayreuth, $H H$ is in this view propagated by Nietzsche an exercise in self-restraint that puts an end to all "feminine" concerns about ideals and "beautiful feelings" (KSA 6, 327). ${ }^{2}$ It is moreover a war, which is fought without any pathos, as he curiously writes, because fighting with pathos would still be "idealism" (KSA 6, 323). Despite such strong-worded statements, the narrative of a general turn against feeling gives at best a partial explanation of Nietzsche's Bayreuth-crisis.

There is another, more enlightening way of reading Nietzsche's crisis. Rather than being a turn away from strong feeling altogether, Nietzsche's turn away from the Wagnerians can be read as itself driven by a strong feeling. On this reading, what bothered Nietzsche about Bayreuth was not the displays of intense feeling per se, but his shock that what he considered the highest feelings were mingled with the lowest motivations. What he found was that Wagner had become "German" and succumbed to the impulse to please the crowd (cf. KSA 6, 323; cf. Janz 1978 I, 708). Nietzsche's error was to go to Bayreuth with an ideal in mind, as he himself attests in a note from 1878 (NL 1878, 30[1], KSA 8, 522). This was an ideal that he

troubling affects (Brusotti 1997, 14), but also free of passions altogether, i.e. apathetic (Brusotti 1997, 228). Even though Brusotti is careful to point out that Nietzsche seems to have had doubts about the issue all along, Brusotti still emphasizes what he interprets as signs of how hard it was for Nietzsche to give up the goal of attaining such a perspective (Brusotti 1997, 188 and 630-632).

2 "Menschliches, Allzumenschliches, dies Denkmal einer rigorösen Selbstzucht, mit der ich bei mir allem eingeschleppten 'höheren Schwindel,' 'Idealismus,' 'schönen Gefühl,' und andren Weiblichkeiten ein jähes Ende bereitete" (KSA 6, 327). 
had himself elaborated and celebrated in the fourth untimely meditation, Richard Wagner in Bayreuth, which was specifically published for the occasion in 1876. This ideal Wagner was a cosmopolitan or over-German [überdeutsch] phenomenon, whose music was above all an expression of the "truth" of pathos, i.e. that honest passion is far better than moralistic hypocrisy and conformism (cf. RWB, KSA 1, 506-507; cf. Janz 1978 I, 712). After his arrival in Bayreuth, it did not take long for Nietzsche to realize that his ideal did not matter and that honesty in matters of feeling was out of the question in the company now gathered; the company of "important" persons such as princes and other wealthy sponsors. ${ }^{3}$ This disappointment, however great it was, did not lead to a rejection of the value of feeling but to the task of purifying feeling. What Nietzsche craves is purity of feeling, and greatly aided by his escape into the mountains he finds within himself an affective ideal that matches his demands. ${ }^{4}$ He then rereads and reinterprets Schopenhauer in the light of his new experience and it is this engagement with his former master, which finally allows him to develop into an independent thinker.

Against this background, I advance the thesis that Nietzsche's focus on affectivity in his analysis of the religious life is a direct result of his rereading and appropriation of Schopenhauer, and that Nietzsche's quarrel is not with heightened feeling per se but with metaphysical and religious interpretations of extraordinary emotions. Herein lies the independent scholarly interest of the ensuing discussion, if one were to disconnect it from the broader arguments of the study. To reiterate, I argue that Nietzsche does not question the value of intense feelings and that he instead only attacks misguided interpretations. That he does seek a certain distance from feeling is undeniable, but that does not contradict his aim. To the contrary, I will seek to show that one can plausibly assume that Nietzsche at least implicitly already in $H H$ understands distance as pathos (cf. BGE 257, KSA 5, 205), and connects "being above" certain feelings with a specific affective ideal. Arguably, $H H$ is to a great extent about articulating this affective ideal of distance, and arguably, Nietzsche struggles to express his experience and to transmit it to his friends and readers. Indeed, we will yet come to ask if he is perhaps right to doubt to what extent he can succeed. First of all, however, the foundations for the interpretation sketched here must be laid through an examination of the foundations of Nietzsche's psychological criticism.

3 "die erbarmungswürdige Gesellschaft der Patronatsherrn und Patronatsweiblein", as he noted in a first draft for the description of his crisis in EH (KSA 14, 492; cf. Janz 1978 I, 720).

4 In fact, Nietzsche himself represented his turn away from the Wagnerians as such in his letters. E. g. in a letter to Mathilde Mayer he justifies his escape from Bayreuth in terms of the discovery of a mood that he metaphorically relates to the fresh mountain air [Höhenluft], a mood so promising that it compels him to break with the Wagnerians and seek solitude: "ich bin auf einem Grad der Ehrlichkeit angelangt, wo ich nur die allerreinlichsten menschlichen Beziehungen ertrage" (KGB II/5, Bf. 734). I present more evidence about this mood and discuss it in detail in the final parts of the discussion on $\mathrm{HH}$. 


\subsubsection{The foundations of Nietzsche's psychological criticism}

$\mathrm{HH}$ is notable for the reason that Nietzsche at the beginning provides a sketch of his method of doing philosophy. ${ }^{5}$ Chapter one introduces the reader to a specific kind of philosophizing that Nietzsche calls historical philosophizing, though it could at least as well be called psychological philosophizing. This latter claim gains support from the very first two passages ("aphorisms") of $\mathrm{HH}$, which announce the new program. The Chemistry of concepts and sensations that Nietzsche calls for is a critical practice, in which the focus of attention is on the construction of our concepts and feelings; be they of a moral, religious or scientific nature. ${ }^{6}$ While this practice mostly results in penetrating psychological analyses of the origins of metaphysical and religious concepts, Nietzsche importantly justifies the new practice as an expression of historical sense. Attentiveness to the various elements that make up unified concepts (e.g. Selflessness, Love etc.) is according to him necessary because of a particular reason. Only such philosophizing avoids what he calls the original sin of philosophers, which is a lack of historical sense. Nietzsche then illustrates what he means by a lack of historical sense by mocking the method with which some philosophers treat the concept of the human: They take the man of today, find certain features and assume that these features have always belonged to mankind. Instead of taking the human beings one encounters in one's own day as paradigmatic ("the human" as aeterna veritas), Nietzsche insists one must as philosopher be sensitive to and open to the reality of change and aware of the historical conditions that shape what we call humanity. (HH I 1 and HH I 2, KSA 2, 23-25)

In itself, Nietzsche's call for more historical consciousness in philosophy is nothing revolutionary in the late $19^{\text {th }}$-century context. He is in fact unusually explicit about his indebtedness to contemporary thought in speaking of historical philosophy as the youngest of philosophical methods to have been developed, even though he at this point fails to mention anyone who would have put the method to practice. A clue can be found in the fact that he connects the necessity of historical philosophizing with the advancement of natural science, writing that the former can no longer be thought of in separation of the latter (HH I 1, KSA 2, 23). A quick glance at Nietzsche's reading is enlightening in this respect. Nietzsche might have made the connection between historical philosophizing and natural science at the very beginning of his turn towards philosophy. Nietzsche read the first edition of Friedrich Albert Lange's

5 Importantly, as Hödl emphasizes, Nietzsche does not abandon the central features of the critical program he explicates in $\mathrm{HH}$, not even in his late works (Hödl 2009, 359). Likewise, Young cursorily notes that the basic thrust of $H H$ is the same as in Nietzsche's later genealogical investigations (Young 2006, 62).

6 A presupposition for the view advanced by Nietzsche is that all those moral, religious and scientific concepts that concern him are made up of analysable components. Aphorism 14 of book one is an attempt to explain how the perception of unity in concepts such as "moral feeling" or "religious feeling” arises in the first place (HH I 14, KSA 2, 35). 
History of Materialism [Geschichte des Materialismus] in 1866, in which the neo-Kantian philosopher among other things discussed recent physiological and psychological research and reflected on their relevance to philosophy (cf. Brobjer 2008, 32-36). Although Lange's work was important in Nietzsche's philosophical development (cf. Stack 1983, 1-2), especially in the late 1860s, there is no evidence to suggest that he reread that book in the years directly leading up to the publication of $\mathrm{HH}$ (Brobjer 2008, 35). In those decisive years, however, Nietzsche became acquainted with the work of British anthropologists who sought to apply the idea of evolution to human history and society; not least Herbert Spencer, J. Lubbock and E.B. Tylor (cf. Orsucci 1996). That Nietzsche thought of the works of these thinkers as intimately connected with natural science can be sufficiently explained with reference to their content. In the case of Spencer, one can also add the fact that Nietzsche read his work as part of an edited series (Internationale Wissenschaftliche Bibliothek), which contained both natural and social science (cf. Brobjer 2008, 64-65). Closer to home, Paul Rée further familiarized Nietzsche with this kind of thinking. So what is it that sets our philosopher apart from others, who were keen to integrate the most recent findings of anthropology, psychology and historical methods into philosophy? In Nietzsche's hands the combination of psychological insight and historical method results in an intensity quite unlike anything to be found in his predecessors and contemporaries. This intensity is the result not of some improvement of the historical method by Nietzsche, but rather derives from the originality and boldness of his psychological vision; reflected in the uncompromising vehemence of his cultural criticism, which is especially evident in his reevaluation of the tradition regarding desire and mood.

The two opening aphorisms already suggest the most important target of his cultural criticism: narrow and outright false interpretations of "the human". How human life is interpreted is important, the aphorisms imply, because interpretations of what it is like to be human and how various phenomena are to be understood in fact shape what life is like. That Nietzsche in the second aphorism explicitly mentions religion, besides politics, as a force that has shaped humanity is an important indicator of that which is to come (HH I 2, KSA 2, 24-25). For once one recognizes that the idea of humanity that reigns in one's own day does not reveal the eternal truth about humans, as Nietzsche here does, a number of critical questions are made possible. How and why does the image of "the human" change? What are the historical and psychological roots of the contemporary construction of "the human"? What instincts, desires and moods does it express? Does it perhaps present a misshapen picture of "the human"? If so, what could be done to change the picture?

As hinted at above, the historical philosophizing that Nietzsche practices in $\mathrm{HH}$ cannot be disconnected from cultural criticism. This at first sight rather banal thesis hides a potential for great conflict, as it is necessary to specify what kind of culture is the target of criticism. That this is indeed the case can be seen in the work of Paul Franco, who most recently has defended the thesis that culture is the central concern 
of $H H$. Franco is of course right to identify the theme of culture as central to $H H$, but his talk of a single problem of culture (Franco 2011, 16), specifically a problem of modern culture, suggests to me a more systematic treatise than Nietzsche in fact delivers. Are there not more than one problems of culture in $\mathrm{HH}$, the most important of which arguably would be the problem of metaphysics? ${ }^{7}$ In Franco's interpretation, metaphysics does form the "deepest substratum of Nietzsche's critical excavation of the problem of modern culture” (Franco 2011, 17). It is, however, anything but clear from Franco's examination of the issue what relations pertain between the different substrata of the purportedly singular problem of "modern culture" and whether they depend in some way on metaphysical errors in the deepest substratum. How, for example, do the chapters Woman and Child or A Glance at the State relate to metaphysics? Resolving the issue lies beyond the scope of this study. Here I will focus on the problem of metaphysics as a cultural problem, which certainly is one of the main concerns of the book.

Firstly, Nietzsche's concern with metaphysics needs to be specified. Nietzsche is not primarily concerned with metaphysics per se, as in classical questions of metaphysical philosophy, but rather focuses on metaphysical interpretations, i.e. metaphysics in and as culture. Characteristic of this psychological approach is his admission that there might be a metaphysical world, but that all attempts to gain knowledge of metaphysical worlds has relied on the very worst methods of reasoning. In short: metaphysical assumptions are the result of passion, error and self-deception [Leidenschaft, Irrthum und Selbstbetrug] (cf. HH I 9, KSA 2, 29-30). Secondly, Nietzsche's attack on the reasoning supporting metaphysics is not limited to the first chapter, Of the First and Last Things. Franco is of course quite correct in his assessment that the first chapter is primarily directed at Schopenhauer (Franco 2011, 17; cf. Heller 1972, 6). To this must be added that the concern with metaphysical interpretations and consequently the engagement with Schopenhauer resurfaces throughout the work, though it is most strongly present in chapters 1, 2, 3 and 4. Instead of systematically working my way through the entire work, I here want to follow one specific trace that is especially relevant for the understanding of Nietzsche's psychological criticism of religion. This is a trace, which leads straight back to Schopenhauer's philosophy.

In order to pick up the trace, it is necessary to return to the first aphorism. Nietzsche there contends that metaphysical philosophy avoided the difficult task of explaining how something could arise from its opposite, e.g. feeling life from

7 Judging from the fact that quite a few commentators on $\mathrm{HH}$ focus exclusively on the problem of metaphysics (cf. Golomb 1989), one could mistakenly assume that there is a consensus. On this issue, I lean in favour of Young, who does not seek to subsume all the content of $\mathrm{HH}$ under one problem of culture, but nevertheless notes that the problem of metaphysics is central to Nietzsche's cultural criticism in the work. Young writes that "The fundamental aim of Human, we have seen, is to hunt down and destroy belief in a metaphysical world", and this is to be done "as a preliminary to constructing a new, post-metaphysical, 'rational' culture” (Young 2010, 249). 
dead matter, intellect from ignorance, truth from lies and so forth, by simply denying that anything of value could have arisen from its opposite. Instead, metaphysical philosophy dreamt up a higher origin for all that which is valued more highly, thus positing a wondrous origin directly from the "thing in itself" (HH I 1, KSA 2, 23). It is precisely this interpretative tendency, or in more Nietzschean words: this method of knowledge, that is the main target of Nietzsche's attack on metaphysics. So what at first sight might seem an insignificant detail in the argument of the aphorism turns out to be the key to understanding the problem of metaphysics as Nietzsche presents it in $\mathrm{HH}_{.}{ }^{8}$ Indeed, its relevance goes far beyond the practice of metaphysical philosophy. We will soon see that Nietzsche thinks this operation of positing a wondrous origin is at least as, if not more present in everyday life as in philosophical reflection and that he thinks his critique rings especially true of those ideas, experiences and emotions that are granted the highest value. Now, however, I will turn to examine the origins of this understanding of metaphysical reasoning, which are to be found in Schopenhauer. As will be shown, a close examination of Schopenhauer's philosophy of religion is essential for understanding Nietzsche's psychology of religion in $H H$ and beyond. Such an examination is also particularly illuminating when it comes to understanding Nietzsche's appropriation of Schopenhauer's thinking in general.

\subsubsection{Approaching Schopenhauer's philosophy of religion as the model for and target of Nietzsche's psychological criticism}

Before I examine the most relevant passages of Schopenhauer's philosophy of religion in detail, some words about the methodical approach taken here are necessary. A good starting point is to be found in the principle that one must resist a naive understanding of the relation between source and influence in order to grasp the character of Nietzsche's reception of other writers. This is because he always reads others with his own projects in mind. So even when he seemingly merely quotes an author or reproduces a viewpoint, only the context of his own projects make his borrowings intelligible.

Even once one accepts that context is king, in the sense that Nietzsche's own projects take precedence over the intentions of his sources, there is in the case of his reception of Schopenhauer a specific tension that cannot be done away with easi-

8 Notably, Nietzsche repeats exactly the same critique at the beginning of Beyond Good and Evil. There, in the second passage, he writes that inventing a divine origin for all that which is valued most highly is the defining mark of metaphysics. Such interpretation "macht das typische Vorurteil aus, an dem sich die Metaphysiker aller Zeiten wiedererkennen lassen; diese Art von Wertschätzungen steht im Hintergrunde aller ihrer logischen Prozeduren" (BGE 2, KSA 5, 16). This fact further testifies to the foundational role of $\mathrm{HH}$ for Nietzsche's later criticism and the importance Nietzsche attached to casting light on the reasoning that begets metaphysics. 
ly. So one might correctly emphasize that Nietzsche's entire criticism of religion cannot be understood on the basis of one source (cf. Hödl 2009, 323). Nevertheless, as Hödl rightly insists, it is of crucial importance for the understanding of Nietzsche's thinking on religion to determine precisely how it relates to Schopenhauer, and this applies especially to the understanding of his early works (Hödl 2009, 321). The shadowy gloom of Schopenhauer's philosophy looms large over that period in which Nietzsche develops into an independent thinker. This means that reading Nietzsche with Schopenhauer in mind is a veritable balancing act. How can one avoid either understating or overstating Schopenhauer's influence? Julian Young, as a prominent example, goes too far as he attempts to understand most if not all of what Nietzsche has to say about religion from the perspective of Schopenhauer's philosophy of religion. In the process, Young elevates Schopenhauer to the status of a standard for judging the merits of Nietzsche's thinking (Young 2006, 10). Not only does this approach prevent Young from appreciating Nietzsche's thinking on religion in its own right, it also leads him to repeatedly overstate the influence of Schopenhauer. ${ }^{9}$ To avoid overestimation, and in order not to give in to the opposite vice of understatement, I adopt an idea first presented by Hödl, who characterizes Nietzsche's reception of Schopenhauer as one of transforming appropriation [anverwandelnde Übernahme] (Hödl 2009, 321-330). This is an idea which deserves serious consideration and more attention than it has hitherto received.

The main thrust of Hödl's argument is that one must attend carefully to the manner in which Nietzsche relates to Schopenhauer (Hödl 2009, 321). According to Hödl, the textual evidence that bears on the issue of Nietzsche's appropriation of Schopenhauer testifies either of a rejection and move away from the core tenets of Schopenhauer's teaching on religion or of a transposition, in which the valuations are subverted (Hödl 2009, 330). This is the case even with those basic tenets of Schopenhauer's theory of religion that retain their importance for Nietzsche's thinking on religion all the way through the late works. ${ }^{10}$ While Hödl, due to the nature of

9 This is especially the case whenever Young discusses the "metaphysical need" in Nietzsche, an issue that I discuss in some detail below. Young's most egregious claim is that Nietzsche never truly abandons the idea that there is a religious need that has to be stilled and therefore comes up with a Dionysian pantheism to serve the function of religion in Schopenhauer's theory (Young 2006, 201). The problem with this claim is that Nietzsche clearly rejects the idea that that religion grows out of one immutable need; instead, religion is based on many different needs and desires. That these needs are historically mutable is something that Nietzsche emphasizes already in $\mathrm{HH}$. Characteristically, Young mistakes the decisive aphorism expounding this historicist view for a discussion of a singular "metaphysical need" (HH I 27, KSA 2, 48; cf. Young 2006, 85).

10 These basic tenets are: 1 . religion is basically mythological and must be interpreted philosophically, 2. Christianity is a form of Platonism, just as religion is metaphysics for the people, 3. Christianity and Buddhism are pessimistic religions, and 4. Christian love is a kind of Mitleid, just as Schopenhauer understood it to be (Hödl 2009, 322). Contrary to Schopenhauer, Nietzsche rejects Christian Mitleid, pessimism and Platonism, and the manner in which he philosophically interprets religion is markedly different. So the foundation is intact, but the evaluation differs. 
his research interest, uses the idea of transforming appropriation to allow for generalizations about the relation in which the younger philosopher stands to the older, I here intend to show how this idea can be applied in a specific context to a specific text. So in the following, I want make a specific claim plausible: a claim that concerns the manner in which Nietzsche appropriates elements of Schopenhauer's thinking for his own ends.

\subsubsection{Nietzsche's appropriation of the "metaphysical need"}

The most important expression of Schopenhauer's thinking on religion is to be found in chapter 17 of the second volume of The World as Will and Representation [Die Welt als Wille und Vorstellung]. ${ }^{11}$ This chapter is called "On the metaphysical need of man” [Ueber das metaphysische Bedürfnis des Menschen] (Schopenhauer 1999, 184). It could be assumed that Nietzsche was influenced by the chapter already based on the fact that he himself makes use of the term metaphysical need. It is, however, not the case, as Young asserts, that Nietzsche "refers constantly to "the metaphysical need"” and that this presumed fact "shows the importance of this chapter as a background to understanding his own philosophy of religion" (Young 2006, 9). In fact, Nietzsche only five times explicitly mentions the metaphysical need in his published works (and all forms of spelling are here accounted for); thrice in $\mathrm{HH}$ (HH I 153, KSA 2, 145; twice in quotation marks: HH I 26, KSA 2, 47 and HH I 37, KSA 2, 61), once in GS (GS 151, KSA 3,494) and finally one last time in $E H$ when describing $H H$ as laying an axe at the roots of that "need" (KSA 6, 328). All of these cases express Nietzsche's rejection of the idea of a perennial metaphysical need. The only neutral use of a related term is the mention of a metaphysical drive [metaphysische Trieb] in BT (BT 23, KSA 1, 148), which also remains the only mention of such a drive in the published works. In the Nachlass of winter 1876 to summer 1877, Nietzsche twice mentions the metaphysical need, both times as "the so-called metaphysical need” (NL 1876, 19[85], KSA 8, 350 and NL 1876-77, 23[164], KSA 8, 464). The only other original mention in the Nachlass, also from the summer of 1877, explicitly criticizes the philosopher who on the basis of a false psychology turns everything into metaphysical need (NL 1877, 22[107], KSA 8, 399). Then there is finally one note from autumn 1880 which is in fact a sketch [Vorstufe] of the criticism of the metaphysical need found in GS (NL 1880, 6[290], KSA 9, 271-272, cf. GS 151, KSA 3,494), and that is all. A charitable interpretation of Young's assertion,

\footnotetext{
11 Another important expression is the dialogue between Demopheles and Philaletes in chapter 15 "On Religion" [Ueber Religion] of Parerga und Paralipomena II. Philosophically, the dialogue adds little to the treatment of religion in World as Will II. The treatment there is also more clear and concise. Though Nietzsche most certainly read the Parerga-chapter, he made no annotations to it in the only surviving copy that was in his possession (Brobjer 2008, 125). For pragmatic reasons, I therefore focus on chapter 17 of World as Will II.
} 
one that would broadly keep his intention intact, could point to the fact that Nietzsche does again and again return to the question what kind of impulses, instincts and needs are at work in religious persons, i.e. what it is that drives people to act religiously. A case in point would be Nietzsche's discussion in his major work on the genealogy of morality of what is perhaps best described as a need for meaning (GM III 1, KSA 5, 339 and 411-412). ${ }^{12}$ In this sense, there is a continuing engagement with questions raised by Schopenhauer's theory of religion, but only because Nietzsche considers said theory so unsatisfying. What Nietzsche is after is a more fitting psychology of religion.

For our task here, which is to establish in which sense Nietzsche relies on Schopenhauer in his discussion of religion in $H H$, considerations about Nietzsche's alternative explanations are as of yet of a secondary importance. The key issue here is that his rather rare references to the metaphysical need cannot be used as evidence in an argument about the importance of chapter 17 of World as Will II as a background for the understanding of Nietzsche's thinking on religion in $H H$, and even less can they be used as evidence for more general claims about Nietzsche's relation to Schopenhauer. This is because Nietzsche has by the time of $\mathrm{HH}$ decisively rejected any positive use of the term metaphysical need; a rejection which is reflected in the fact that he no longer uses the term after GS. Therefore, I here take a different approach to establishing the indebtedness of Nietzsche's thinking in $H H$ to Schopenhauer. I intend to make plausible that some of the critical manoeuvres Nietzsche makes in $H H$ can only be understood against the background of the Schopenhauer-chapter. Thus, I will draw on evidence from within the text to support the view prevalent in historical scholarship that Nietzsche not only read but studied the chapter carefully. ${ }^{13}$

According to Schopenhauer, religion is about the thing-in-itself [das Ding an sich] just as philosophy but caters to the populace that is unable to think their way to the truth. If the common folk can't think properly, they certainly can feel. Religion represents and connects to the thing-in-itself through allegory. In this view, mysteries, obscure rites and even absurdities are not corruptions of religion. Schopenhauer explicitly writes of such aspects of religion that they are the only way that one can make the common folk feel what they can't grasp in thought; namely that there is

12 In a late note from autumn 1887, Nietzsche also explicitly connects the felt need for another world with a failure to find meaning within this world (cf. NL 1887, 9[73], KSA 12, 374).

13 In the case of $H H$, the prevalent view is supported by the fact that Nietzsche made extensive annotations when he reread the second volume of The World as Will and Representation in 1875 (Brobjer 2008, 125). More generally, it can be added that: "Nietzsche continued to read, annotate, and make excerpts from Schopenhauer's writings almost every year, even after his break with Schopenhauer, to the very end" and that "Most of Nietzsche's continued reading of Schopenhauer was of his two main works, Die Welt and Parerga" (Brobjer 2008, 32). 
a wholly other realm beyond appearance (Schopenhauer 1999, 192). ${ }^{14}$ So the point of allegory, for Schopenhauer, is to allow the believer to feel, to intuit, the presence of a more fundamental, completely different level of reality.

Nietzsche of course rejects Schopenhauer's theory of the allegorical nature of religion in $H H$ (HH I 110, KSA 2, 109-111), a fact which has not escaped the notice of scholars (cf. Hödl 2007, 155 and Franco 2011, 36). Nevertheless, Nietzsche grants Schopenhauer's model a paradigmatic status insofar as metaphysical and religious reasoning is concerned. He admits as much in the very same aphorism that criticizes the allegorical interpretation of religion, when he writes that through Schopenhauer's interpretation of religion very much can be gained for the understanding of religion (HH I 110, KSA 2, 110). ${ }^{15}$ As I understand Nietzsche, he thinks that Schopenhauer is not simply plain wrong. He rather thinks that Schopenhauer's thinking builds on and repeats an erroneous way of thinking typical of religion. So in a sense, one could say that Nietzsche treats Schopenhauer not only as a philosopher who presented a theory of religion but as a high priest, in whose thinking religious passions are articulated in philosophical terms. Less dramatically stated, Nietzsche perceives an affinity between Schopenhauer's thinking on religion and religious thinking in general.

Now we can begin to see why it is that in Nietzsche's own elaborations in $H H$ the Schopenhauerian structure remains intact, although the thing-in-itself is removed from the picture. For what remains when that which allegory supposedly gets at is removed? Simply feeling. More precisely: all that in metaphysics, religion and art which makes one feel as if there were another world beyond this one, all those experiences which lead one to posit a metaphysical world, all that which in Schopenhauer's view makes the existence of a metaphysical world something that can be felt. In other words, all that remains which leads one to speak of a metaphysical need in the first place. No wonder then that Nietzsche devotes special attention to religious interpretations of feeling-states in his discussion on religion in $\mathrm{HH}$. For in order to liberate himself and his readers from the Schopenhauerian view that certain experiences truly allow one to intuit a metaphysical world, Nietzsche has to argue that what really is going on is interpretation, and false interpretation at that. Then there still remains the task to explain, why certain affective experiences are prone to be interpreted falsely in the first place. Both of these critical tasks are present in $H H$, though the focus is overwhelmingly on the former. To conclude: Even as Nietzsche's indebtedness to Schopenhauer has been recognized in scholarship, this important affective aspect has been overlooked with the result that Nietzsche's

14 "diese sind eben der Stämpel ihrer allegorischen Natur und die allein passende Art, dem gemeinen Sinn und rohen Verstande fühlbar zu machen, was ihm unbegreiflich wäre, nämlich daß die Religion im Grunde von einer ganz andern, von einer Ordnung der Dinge an sich handelt” (Schopenhauer 1999, 192). 15 He writes specifically that “... we can gain a great deal for the understanding of Christianity and other religions from Schopenhauer's religious-moral interpretation of human beings and the world...” (Handwerk 1997, 87; HH I 110, KSA 2, 110). 
focus on emotions in $H H$ must seem arbitrary if not incomprehensible. That Nietzsche rejects Schopenhauer's allegorical understanding of religion has led scholars to ignore the role played by feeling in the very passage in which Schopenhauer writes about allegory. As a consequence, it has not been adequately recognized, in what specific sense Nietzsche's psychological take on religion in $H H$ draws on Schopenhauer's thinking. The following interpretation of Nietzsche's psychology of religion in $\mathrm{HH}$ is in this sense to be understood as a contribution to recognize not only the ways in which he distances himself from Schopenhauer's philosophy, but also how he remains tied to it. ${ }^{16}$

\subsubsection{Nietzsche's psychology of religion and salvation}

In the chapter The Religious Life, Nietzsche leads the reader into the topic of religious interpretations of emotions through a brief discussion of pain. When beset by pain, he claims in aphorism 108, one can either seek to rid the cause of the ill or reinterpret the experience. This second way, namely that of reinterpretation, is the way of both religion and art. At first Nietzsche speaks of reinterpretation as a matter of justifying pain, e.g. with reference to God's justice. Then Nietzsche adds the really interesting observation: changing one's judgement about a painful experience is only one part of the picture, one can also seek to transform the emotional experience more directly. Tragic art, he writes, has its origin in a "a pleasure in pain, in emotion generally" (Handwerk 1997, 85; HH I 108, KSA 2, 107). Although this statement that one can take pleasure in emotion for its own sake, even if the emotion were painful, is about tragic art it is also of utmost importance to Nietzsche's reflections on religion in $\mathrm{HH}$. For in this work, analysing such transformations of emotions through interpretations is a crucial ingredient of Nietzsche's formula for challenging Schopenhauer's view that certain experiences in fact point toward a realm behind appearance.

Throughout the chapter there are a few longer passages as well as shorter aphorisms that seem to stand on their own; digressions unconnected to the more systematic chains of thought. Nevertheless, most of them contribute to the discussion about the interpretation of emotion. One such freestanding aphorism is Nr. 120, in which Nietzsche mocks "all religions" for making use of the all too human tendency to think that those opinions which please the emotions also must be true (HH I 120, KSA 2, 120). Such aphorisms reinforce the criticism of the more systematic passages. This is the case even in those aphorisms that concern the "truth" of religions and religious interpretations of nature. The key reason for Nietzsche to reject the Schopenhauerian understanding of the allegorical nature of religion is that one does not need

16 When it comes to the interpretation of $\mathrm{HH}$, Peter Heller was the first to recognize the importance of such an endeavour, when he in a footnote tentatively suggested that interpreters should not only spell out those points in which Nietzsche distances himself from Schopenhauer but also the affinities that remain (Heller 1972, 6). 
to assume that religion has any meaningful relation to truth in order to explain religion. The origin of religion is not to be found in a realm of metaphysical truth but in emotion that guides reason astray; "For every religion has been born out of fear and need” (Handwerk 1997, 88; HH I 110, KSA 2, 110). Nietzsche's reflections on the cognitive aspects of religion can hardly be considered original when one takes account of his knowledge of the leading British anthropologists of his time (cf. HH I 111, KSA 2, 112-116; Orsucci 1996). What merits attention here is rather to what use Nietzsche puts his reading. Nietzsche effectively creates an analogy between erroneous interpretations of nature and erroneous interpretations of our inner nature. The error-theory of religious cognition that Nietzsche advances thus serves an important role in his argument about the interpretation of emotional states. In aphorism 126 Nietzsche explicitly talks about the The art and force of false interpretation in this sense, when he asserts that all those extraordinary experiences that are associated with saints are well-known pathological states that are only interpreted religiously (HH I 126, KSA 2, 122). What emerges here is an alternative interpretive scheme, which builds on Schopenhauer's theory of religion, while rejecting its "truth".

The passages starting with aphorism 132, Of the Christian need for salvation, are of a more systematic character, and provide a particular example in which Nietzsche applies his interpretative scheme and develops his argument. ${ }^{17}$ It is noteworthy that Nietzsche explicitly sets his psychological explanation apart from the psychological approach taken by Schleiermacher, whose influence on $19^{\text {th }}$-century German thinking about religion should not be underestimated (see chapter 2 of this study). Curiously, Nietzsche's only objection to that tradition relates to what he perceives to be the intentions of its practitioners. So even as Schleiermacher purported to explain religious feelings, Nietzsche contends, the goal was always to support the Christian religion. This goal, it is implied, distorted the interpretation. Needless to say, Nietzsche dares a different interpretation of religious feelings, one that is not bound by such a goal. Still, Nietzsche cannot be seen as being entirely opposed to said tradition since he implicitly agrees that religious feeling is the proper object of the psychology of religion. (Cf. HH I 132, KSA 2, 125-126.)

Basically, Nietzsche claims that the need for salvation can only arise if one is dissatisfied with oneself. Simply being dissatisfied, however, is not enough. The Christian compares himself with his God, an ideal that is completely free from egoistic motives. Doing so he puts himself into a state in which he necessarily feels that he is bad: Being incapable of fully non-egoistic actions, he begins to loathe himself and fear the retribution of his ideal. Thankfully, there is salvation. The feeling of despising himself is not constant, but eventually gives way to a freer disposition. The natural feeling of self-love reappears, but is not interpreted as such. The joyful mood is instead interpreted as a gift from God, as grace, as a foretaste of salvation. The felt

17 Because of the systematic character of the discussion, some scholars speak of Nietzsche developing a psychology of the need for salvation (cf. Hödl 2007, 153). 
love is interpreted as Love, an external power with a divine origin. (HH I 132-135, KSA 2, 125-129)

We are not here concerned with the question to what extent Nietzsche's depiction hits the spot; suffice it to say that it is hard to be contented with his explanation, as there would be so much more to say about the issue. Instead, we want to note how the passages in question form a particularly potent example of Nietzsche's interpretive scheme. First, he examines the cognitive and affective parts and moments that make up this particular psychological "need". Then he shows how the religious interpretation of the feelings involved covers up the actual origins of the feelings. This is done by coming up with a "wondrous origin" that hides its complex natural origin. In conclusion, Nietzsche writes that a false psychology is a presupposition for being Christian and feeling a need for salvation. And what is it that makes a psychology false? Fantastic interpretations of psychic processes, "a certain kind of fantasizing in the interpretation of motives and events" (Handwerk 1997, 104; HH I 135, KSA 2, 129), which on the grounds of its centrality to the whole chapter and its importance in the preceding passages, I take above all to refer to the tendency of positing a "wondrous origin" in another world for all extraordinary experiences. This is according to Nietzsche the process whereby experience is transformed into religious experience and emotion into religious emotion.

After the passages on salvation, Nietzsche continues his analysis of the religious life with an examination of asceticism and sainthood. There is no reason to examine these passages in detail at this point (see section 4.2.5), as Nietzsche basically repeats the same pattern of interpretation. In all ascetic practices, however complex and hard to explain, he discovers the same glorying in emotion for its own sake, “pleasure in emotion as such" (Handwerk 1997, 107; HH I 140, KSA 2, 133). Nietzsche sums it up in aphorisms 142 and 143: The saintly person's state of mind is made up of components that in themselves are familiar, but take on a different colour when they are put together and interpreted religiously. Along with unsurprising virtuous feelings such as humility, other feelings such as egoism, vengefulness and lust to rule are some of the components of saintliness. In the saintly person's mind and more crucially in the minds of religiously minded interpreters these components give way to the overall impression of holiness, which of course is of divine origin. Thus, the historical importance of saints is tied to religious belief in general: the belief in saints supports belief in God and vice versa. (HH I 142 and HH I 143, KSA 2, 137-139)

Nietzsche does not as rigidly apply such an interpretative scheme in any of his later works. Nevertheless, the results of his application of the method of historical philosophizing laid the groundwork for his later critical efforts. Two ideas that surface in $H H$ are especially instructive in this regard, and worth noting. Firstly, Nietzsche seems to suggest in $H H$ that intense emotional experiences are especially prone to be interpreted religiously. But why would this be the case? $\mathrm{HH}$ provides no clear answer, so we will leave that question for now and content ourselves with not- 
ing that $H H$ contains the seeds of an explosive idea. ${ }^{18}$ Secondly, and perhaps more importantly, Nietzsche's idea that the interpretation of feeling can transform feeling has radical consequences once thought through. Due to this foundational idea, it is no wonder that Nietzsche's historical psychologizing leads him to a diagnosis and criticism of the spiritual-affective predicament, the mood, of his own time. Although Nietzsche later expands on and improves the diagnosis, this early expression is worth looking into, if only to appreciate the development of his thinking the better.

\subsubsection{The history of emotions and Nietzsche's diagnosis of his time}

Already the second aphorism of the third chapter, Sorrow is knowledge, implicitly relies on the idea that the cultural and religious education of the past have made modern humans especially soft. Bereft of religious consolation, Nietzsche bluntly states that contemporary humanity is at risk when facing the harshness of reality, especially the well-founded knowledge presented by modern science. Nietzsche then abandons the topic as fast as he introduced it by referring to the possibility of a lighthearted, cheerful response to knowledge, but the historical problem hinted at here informs much of his later thinking on the issue, especially in D and GS (HH I 109, KSA 2, 108-109).

In aphorism 130 Nietzsche again approaches the emotional legacy of thousands of years of religious education. He writes about religious feelings that were created and nurtured long ago in the past by religious cults. He specifically mentions the Catholic church as an organization that had mastered all the means to transport humans into moods and states of mind beyond the everyday. This original process of cultural creation is according to him the source of many moods [Stimmungen] of the sublime kind, of feelings of hope and premonition that "now exist in the soul". He furthermore notes that even as the religious foundations of such feelingstates have crumbled, the results of this process remain with us. (HH I 130, KSA 2, 123) Such moods, he writes, can now be encountered in the arts, especially in music, but also in philosophy wherever the author plays with metaphysical hopes (HH I 131, KSA 2, 124). So Nietzsche at first look seems to imply that we are not easily rid of emotions that have become part of our cultural heritage. Such an interpretation is still only partially true. One must indeed beware of such an interpretation, however tempting it is. According to Nietzsche, it is strictly speaking not the case that the emotional configurations of the past would determine the future directions of feeling. In the very same aphorism in which he describes various Religious afterpains he speaks of the taste for religious feelings as a passing need, as "an acquired and

18 I return to the question and discuss Nietzsche's late thinking on the matter in chapter 7 amidst the discussion on Nietzsche's late ideal. 
consequently also a transitory need" (Handwerk 1997, 99; HH I 131, KSA 2, 124). ${ }^{19}$ It is near at hand to add that the taste that Nietzsche diagnoses in (himself and) his contemporaries might suffer the same fate as the taste for antique sacrificial rituals. In aphorism 112, Nietzsche muses on the fact that "we" (i.e. he and his contemporaries) no longer are able to fully understand how in certain times obscenity could go together with religious feeling; e.g. in Dinoysian rites as well as in medieval Easterplays. The historical record testifies that such combinations of feeling have existed, but we cannot bring ourselves to anything resembling the feeling that must have been felt. Similarly, Nietzsche concludes, combinations of feeling that still exist in his day, such as a union of the sublime and the burlesque, might not be understood in the future (HH I 112, KSA 2,116). It is striking that Nietzsche here only mentions the possibility of feelings being lost to posterity. By the same logic, however, it should be possible that entirely new combinations of feeling arise, and perhaps even new feelings; feelings so distinct from past experiences that new names are needed for them.

There is thus an uncertainty in Nietzsche's take on the history of emotions in $H H$ that deserves to be spelled out in detail. Nietzsche suggests that at least some religious emotions have a history in the sense that they were born in a specific time and will pass away some day. That means that some emotions would never have been felt if it were not for centuries of religious practice. If "religious emotions" are in a sense creations of religious practice, can the interpretation of feelings in fact give birth to new feelings? Or is it after all only the case that various practices can condition or influence the way specific emotions are felt, thus transforming them? Are there only "natural", basic emotions that are interpreted in various ways or are at least some emotions better understood as cultural constructions in a more thoroughgoing sense? Nietzsche never articulated such purely theoretical questions, yet the issue is of utmost importance in his later projects. Instead of providing a theoretical answer, answers emerge in his cultural criticism. In the case of the third chapter of $H H$, all there is to say is that it would seem that Nietzsche prefers to speak of interpretation rather than of creation. Since these questions define the limits of cultural criticism when it comes to emotions, we will pursue them further by considering what Nietzsche has to say about the history of emotions in chapters four and five. These chapters are particularly interesting, because Nietzsche in chapter four deals with art and artists and in chapter five with what he considers higher culture.

19 "eines gewordenen und folglich auch vergänglichen Bedürfnisses" (HH I 131, KSA 2, 124). A similar rejection of the idea of a universal metaphysical need can be found in the chapter on the state, where he describes the needs that the "universal" Catholic church served as fantastic creations: "auf Fiktionen beruhenden Bedürfnissen, welche es, wo sie noch nicht vorhanden waren, erst erzeugen musste (Bedürfniss der Erlösung)" (HH I 476, KSA 2, 311). 


\subsubsection{The history of emotions in chapters four and five: From art to higher culture}

The discussion on art in $\mathrm{HH}$ sets off with yet another reminder of the problem introduced in aphorism 1, i.e. the problem of assuming a wondrous origin for that which is valued. This time the focus is on the "perfect" artwork. For some reason, Nietzsche suggests, "we" are accustomed not to let questions about origins interfere with our experience of art; instead, "we" act as if that which is perfect cannot have become. In other words, we would prefer to blend out any knowledge of the process of artistic creation. One would rather believe, and perhaps the artist would rather have one believe (cf. HH I 155, KSA 2, 146), that the artwork has its origin in improvisation, a miracle-like instant of creation (HH I 145, KSA 2, 141). Nietzsche does not here use the word inspiration, but that ideas of inspiration are the main target can be seen in aphorisms 155 and 156 that repeat and build on the criticism of the opening aphorism. But why is it so hard to entertain a rational view when faced with great art? What psychic mechanism is it that supports mystifying interpretations? The best Nietzsche has to offer for an answer is the suggestion that "we" seem still to be captives of an age-old mythological impression (HH I 145, KSA 2, 141).

So the fourth chapter opens up with a strong statement of the power that historical forces wield over us, and much of the chapter continues in the same vein. The weight that Nietzsche gives to art in his critical project derives from what he takes to be the ability of art to wake up such historical forces within us (HH I 147, KSA 2 142-143). This potential makes art dangerous, in the same way as religion, because it works to temporarily ease spirits by turning them away from their predicament in time, instead of striving to overcome the conditions in their time that create the need to be “eased" (HH I 148, KSA 2, 143). His earlier and later writings considered, it is remarkable that Nietzsche here denies artistic creation the possibility of presentand future-orientation. ${ }^{20}$ He goes so far as to describe the artist as necessarily turned toward the past (HH I 148, KSA 2, 143). That he then finds the backward looking gaze of art troublesome is understandable, since he takes the past to be above all religious.

In aphorism 150, Nietzsche explicitly diagnoses his own time as one in which art has taken a wealth of religious feeling upon itself, though he does add that similar

20 That art can show the way toward a desirable future is a conviction that informs the entirety of The Birth of Tragedy. According to Franco, Nietzsche still subscribes to this view in the fourth untimely meditation of 1876, Richard Wagner in Bayreuth, where he ascribes Wagner's art the potential to initiate a "reform of the world" (Franco 2011, 10). Janz sceptically notes that Nietzsche's comments in that direction can be read as referring to himself, and that he might actually at this point already deny art and Wagner a stake in the future (Janz 1978 I, 712-713). Be that as it may, one must concede, as Janz does, that when it actually comes to opening the future, Nietzsche relies on artistic means, not least the fictional character Zarathustra (Janz 1978 I, 713). The conviction that opening the future is a creative process, a process at least akin to artistic creation if it cannot after all be called artistic creation, informs Nietzsche's thinking from GS onward (cf. GS 58, KSA 3, 422). 
transfers of feeling have to a lesser extent taken place in politics and even in science (HH I 150, KSA 2, 144; cf. HH I 472, KSA 2, 304). It is above all in art that the "metaphysical need" troubles the free spirit, as aphorism 153 shows. In this aphorism that undoubtedly contains an autobiographical element, Nietzsche writes of the "strength of the metaphysical need", and admits that the highest artistic expressions bring to life a long-silenced and almost broken "metaphysical string" in the free spirit. He illustrates this by mentioning how certain parts of Beethoven's ninth symphony elicit a feeling of floating far above the earth with "the dream of immortality" in one's heart. Such an experience creates a longing in the free spirit for the person who could lead him back to metaphysics or religion (HH I 153, KSA 2, 145). Nietzsche's choice of words comes close to validating the Schopenhauerian interpretation that through music one can experience the timelessness of the thing-in-itself. Indeed, it is almost as if he would after all accept the existence of a metaphysical need and the aesthetics of redemption through art. Yet at the end of the aphorism, Nietzsche plays down any hope that he might return to the Schopenhauerian view by bluntly stating that in such cases where art plays on metaphysical hopes the intellectual character of the thinker is put to the test. Intellectual integrity must triumph over vague longings (HH I 153, KSA 2, 145). It is in this sense that the title (Art weighs down the thinker's heart) of the aphorism should be understood; art troubles the heart of the thinker by waking up religious and/or metaphysical feelings of past times. That the task is not simply to consign religious feelings to the past but to become aware of their historicity in order that they might lose their power to compel is a thought that appears frequently in the aphorisms of chapters four and five.

In $H H$, Nietzsche denies art any constructive role in working for the future and even goes so far as to suggest that art is coming to an end. (HH I 222, KSA 2, 185 186 and HH I 223, KSA 2, 186). In the historical scheme of $H H$, scientific man is an outgrowth of and development beyond artistic man. Artistic man in his turn would seem to have inherited a wealth of religious feeling from religious man. ${ }^{21}$ Yet these are not the rudiments of a straightforward replacement theory. Nietzsche does not make the simplistic claim that scientific man replaces artistic man who replaced religious man. As a type, scientific man does not act out the same drives as any of the types from which it has developed. Though he too has inherited a wealth of religious feeling, he is not defined by this inheritance. The higher culture (of scientific man) that Nietzsche describes in the fifth chapter is characterized by a multitude of drives, and is therefore according to him misunderstood by those scholars

21 "Man könnte die Kunst aufgeben, würde damit aber nicht die von ihr gelernte Fähigkeit einbüssen: ebenso wie man die Religion aufgegeben hat, nicht aber die durch sie erworbenen Gemüths-Steigerungen und Erhebungen. Wie die bildende Kunst und die Musik der Maassstab des durch die Religion wirklich erworbenen und hinzugewonnenen Gefühls-Reichthumes ist, so würde nach einem Verschwinden der Kunst die von ihr gepflanzte Intensität und Vielartigkeit der Lebensfreude immer noch Befriedigung fordern. Der wissenschaftliche Mensch ist die Weiterentwickelung des künstlerischen.” (HH I 222, KSA 2, 185) 
[Gelehrte] who besides a drive for knowledge [Wissenstrieb] only have an acquired religious drive. In this sense, he disapprovingly mentions those would see only a misplaced search for religious feeling in modern science: "Indeed, people who are only religious understand even science as a search for religious feeling...” (Handwerk 1997, 190; HH I 281, KSA 2, 230)

How then does the free spirit go about with his problematic inheritance? What will Nietzsche's scientific man do with the wealth of feeling that he inherits? In $\mathrm{HH}$ it would seem above all that he will treat them as objects of knowledge and reflect upon them. This reflection is at once both self-reflection and reflection on the past. As objects of knowledge, religious feelings lose their immediate power to compel; i.e. their power to bind the free spirit to a religious point of view. Nevertheless, the historical sense of the free spirit allows him to see their value. This value he expresses with striking metaphors:

What is best in us has perhaps been inherited from the sensations of earlier times, which we can scarcely approach in an immediate way any more; the sun has already gone down, but the heaven of our life still glows and shines from its presence, even though we no longer see it. (Handwerk 1997, 152; HH I 223, KSA 2, 186)

In other words, our most noble sentiments derive from a past that is becoming increasingly distant. Does that mean that all higher feelings could be lost in the future? This question is at the heart of the important final aphorism of chapter five, which similarly emphasizes the value of religious and artistic passions as objects of knowledge.

The aphorism, entitled Forward, views the task of the free spirit from the perspective of an open future. From this viewpoint, the religious heritage of the free spirit is nothing to scorn. After all, such feelings might one day no longer be accessible. As long as they are accessible, and as long as they are viewed from a distance, they allow the free spirit a fuller understanding of the past. Importantly, Nietzsche underlines that this understanding reveals not only where mankind can no longer go in the future but also where it must not go. That which motivates this claim is a vision of the future. Living only for knowledge, the free spirit will in self-reflection see the emergence of future cultures. Irritatingly, Nietzsche does not specify how this is to be understood. It is near at hand to suggest that because self-reflection here refers to the kind of reflection on morality, on feelings and on knowledge that he has practised in $H H$, new moralities, new feelings and new kinds of knowledge will emerge out of it. The evidence is too scarce, however, to say anything definite about how the "new" is here to be understood. What he does manage to convey through his presentation is his conviction that there is joy in this vision. Switching to the personal level at the end of the aphorism, Nietzsche praises the ideal of knowledge in colourful language ("no honey is sweeter than knowledge" etc.) and goes as far as to promise the free spirit a good death: "Toward the light - your final movement; an exulting shout of knowledge - your final sound.” (Handwerk 1997, 194-196; HH I 292, KSA 2, 235-237) 
Now we can see that Nietzsche denies the artist any stake in working for the future only to give this task to the free spirit or "the scientific man". The intensity of feeling that characterizes religious and artistic man is in no way lessened, it is rather taken to the next level and heightened in self-reflection. The self-reflective activity of the free spirit, which on the basis of the aphorisms examined can hardly be considered dispassionate, contributes to bringing forth "future humanity". Still, one cannot help but notice that there is something missing here; namely a stronger statement of an active creation of the future and a vision of how this is to be done.

\subsubsection{Conclusion: Nietzsche's attack on religion and metaphysics in $\mathbf{H H}$}

The focus of Nietzsche's attack on metaphysics and religion in $\mathrm{HH}$ is on feeling. He turns feelings that are prone to be interpreted metaphysically into objects of knowledge in order to reflect on them. In this project, he makes use of Schopenhauer's philosophy of religion. While Nietzsche rejects Schopenhauer's theory of the allegorical nature of religion in so far as it assumes that religion really connects the believer to metaphysical truth, he does think religion is primarily about making one feel as if there were a "higher reality". In this sense, and in this sense only, Schopenhauer's metaphysics provides the foundation for Nietzsche's psychology of religion. That Nietzsche's psychology of religion in $\mathrm{HH}$ is an achievement of independent thinking is beyond any doubt, which shows how fitting the idea of transforming appropriation is when trying to understand the relation between Nietzsche and Schopenhauer.

At the core of Nietzsche's criticism of religion in $H H$ there is an unresolved tension. On the one hand, Nietzsche implies that acquiring knowledge into the origin of one's religious needs is enough to make them disappear, as if those affective forces which make up the "metaphysical need" were like unto some common delusion that reason can effortlessly dispel. This crudeness is expressed occasionally in concluding sentences, e.g. "with the insight into this origin, that belief falls away" (Handwerk 1997, 102; HH I 133, KSA 2, 127) or "With the insight into this confusion of reason and imagination, one ceases to be a Christian." (Handwerk 1997, 104; HH I 135, KSA 2,129) Such statements contrast with and possibly contradict what Nietzsche on the other hand emphasizes repeatedly, which is that religion continues to wield an immense power through emotions, first and foremost those encountered in the arts. Perhaps the statements quoted above are best read as indicating only a distancing that is a first step; a distancing that allows one to no longer call oneself a believer. The real task, however, concerns the emotional legacy of the past; the configuration of mood bequeathed by tradition. Given that religion, and especially that which Nietzsche considers problematic and worth questioning about religion, is more a matter of feeling than propositional belief, one can ask whether a merely intellectual attack on religion is ever enough. This ambivalence serves well as a sceptical starting point for the following investigation into what has been called Nietzsche's use of mood in $H H$. 


\subsection{Nietzsche's use of mood in $\mathrm{HH}$}

Does Nietzsche make creative use of his psychological thinking about mood in his writing in $\mathrm{HH}$ in the sense of trying to influence the reader? If yes, how exactly and to what end? Is understanding the mood or moods that are expressed in $\mathrm{HH}$ essential to understanding the philosophical project of the book? Can Nietzsche's criticism of religion in the work be fully understood if one ignores the question of mood altogether? Jacob Golomb has presented a thesis regarding Nietzsche's use of mood in $H H$ that can be read as an attempt to answer precisely those questions, which means that it is of great interest to us and cannot be overlooked (Golomb 1989). ${ }^{22}$ According to Golomb, Nietzsche uses mood in $\mathrm{HH}$ to freeze the metaphysical need (Golomb 1989, 162). A critical engagement with Golomb's efforts presents an opportunity to highlight some of the methodological and interpretative problems involved in placing mood at the centre of investigation. Despite the critical emphasis that characterizes the sections on his work, an emphasis which is to be understood as much as self-criticism as criticism of Golomb's scholarship, I will seek to expand and develop Golomb's arguments where possible. In other words, I begin by interrogating Golomb's work, whereafter I expand on his analysis in order to provide as full a picture as possible of the role of mood in $\mathrm{HH}$.

\subsubsection{Jacob Golomb's thesis on Nietzsche's use of mood}

According to Golomb, Nietzsche's use of psychology in $H H$ is misunderstood if one only thinks of it as a matter of him using psychological knowledge to argue against metaphysics. Of course, this is something that Nietzsche does but he also makes use of psychology in a sense that has little to do with the refutation of specific metaphysical beliefs. Instead the "main concern in his application of the psychologistic method is to evoke a mood of deep suspicion and distrust regarding metaphysics" (Golomb 1989, 169). By instilling a mood of doubt in the reader, Nietzsche would in this view seek to effect an affective transformation that would make a direct refutation of metaphysical arguments unnecessary (cf. Golomb 1989, 170). The result would be a freezing of the metaphysical need from which all interest in metaphysical questions springs.

22 Golomb presents his ideas on mood in $H H$ as part of a larger thesis about the therapeutic aims of Nietzsche's philosophizing, which involves 1) using mood to "freeze" destructive habits and 2) opening a psychological perspective that entices the reader to reactivate suppressed power (Golomb 1989, $14-15$ and 20). There as well as in a later publication, Golomb at times seems to imply that his thesis about Nietzsche's use of mood to freeze the metaphysical need applies not only to $H H$ but to Nietzsche's philosophy more generally (Golomb 1989, 14-16; cf. Golomb 1999, 2-6). For reasons of clarity, I will here restrict the discussion to $H H$, as Golomb's reading of the work is the foundation for his more ambitious thesis about the therapeutic aims of Nietzsche's philosophy. 
This aspect of Nietzsche's historical philosophizing, or what Golomb calls his "psychologistic method", intuitively hits the spot, i.e. it catches at least some of what is going on in $H H$. The scholar still hast to ask on what grounds the claim rests. The lack of clear evidence for Golomb's thesis is problematic. Golomb himself recognizes the difficulty by stating that as Nietzsche did not "articulate his method explicitly", one must inductively reconstruct his method by analysing his writings, especially those that deal with psychological themes (cf. Golomb 1989, 162). There are three fundamental problems with this approach; two of a general nature and a third relating to the manner in which he undertakes the reconstruction. The first problem is that Nietzsche does at least provide sketches of the method he calls historical philosophizing (cf. HH I 1 and HH I 2, KSA 2, 23-25) and nowhere mentions that the goal of this method would be to instill a mood of doubt. The second problem is that the procedure amounts to a reconstruction of authorial intention on the basis of nothing more than a reading of the authored book. While such an approach cannot be rejected a priori, it does provide reason to put the evidence presented under close scrutiny and to ask if there is any additional evidence that should be taken into account. The third and final problem is that in this particular case it also seems that Golomb, when formulating his thesis, has not so much relied on the contents of $\mathrm{HH}$ as on Nietzsche's own later statements concerning the book.

The interpretation of $\mathrm{HH}$ as "freezing the metaphysical need" has its roots in Nietzsche's own interpretation of the work in Ecce Homo, which was completed in 1888 (cf. Golomb 1989, 172). There, about eleven years after the publication of the first version of $\mathrm{HH}$ in 1877, Nietzsche looks back at his earlier works with a marked distance. Much of what he has to say is hard to disagree with. Compared to BT, and even to the untimely meditations, the tone of the work has undergone a marked change. Nietzsche writes: "The tone, the timbre is completely different: people will find the book clever, cool, perhaps harsh and mocking." (Large 2007, 55; KSA 6, 323) This description is true to much of the work, though we will yet come to ask if there is not more to say about the matter. At this point, the most urgent question that vexes the scholar is whether one can with any certainty determine if the cool tone was put into the work intentionally and if it was made thus to achieve a specific effect. If the answer is positive one must inquire how it was achieved; whether through the philosophical contents alone, or whether it also depends on the manner of presentation, i.e. choice of style, tone and perhaps even the aphoristic form. To these questions one finds no answers in EH. There Nietzsche simply describes what happens in the work, as if it were from the outside:

One error after another is calmly put on ice; the ideal is not refuted - it dies of exposure... Here, for example, 'the genius' is freezing; a long way further on freezes 'the saint'; beneath a thick icicle 'the hero' is freezing; in the end 'belief', so-called 'conviction' freezes, even 'pity' is growing considerably cooler - almost everywhere 'the thing in itself' is freezing to death...

(Large 2007, 56; KSA 6, 323) 
To find out whether or not there are any unambiguous answers to our questions in the original publication itself, we will now examine the text of $\mathrm{HH}$; beginning with some general observations and a particularly promising aphorism, before examining those passages that Golomb draws on to support his thesis.

\subsubsection{Aphorism 38 and the temperature of $\mathbf{H H}$}

Not a single passage in $H H$ mentions the freezing of beliefs, feelings or needs through the word employed in EH [erfrieren], but the work does contain vocabulary suggestive of coldness. Most notably, Nietzsche does at one point employ words such as wintery [winterlich], cool [kühl] and cold [kalt] in an important discussion on the usefulness (and harm) of psychological observation. Aphorism 38 of book one is indeed particularly instructive for any reconstruction of authorial intention, when it comes to Nietzsche's possible use of mood in the work. Nietzsche here presents his view on the nature of scientific inquiry in general. Science, he writes, as the reflection of nature in concepts [Nachahmung der Natur in Begriffen], does not have any final goals. If science has done any good, it has done so unintentionally, he consequently contends. This scientific view of things, he continues, might seem too cold [zu winterlich], for some people, but there are people for whom almost no air is cold and clear enough as well as people who would desperately need some cooling down. Before ending the passage he repeats this emphasis on relativity by writing that as there are individuals and even peoples that are so serious as to need trivialities, there are others that are so irritable and excitable as to need heavy burdens as a matter of health. Nietzsche finally asks whether not the more spiritual humans of his own time, adding that the appearance of this time suggests to him a world more and more on fire, should seek out all cooling means at hand in order to stay so moderate and composed as they still are, so that they eventually might serve as a mirror (i.e. as self-reflection) of the time. (HH I 38, KSA 2, 61-62)

Let us pause to consider the significance of this passage. Two points that can be made on the basis of the passage strike me as particularly fruitful for finding answers to our questions. Firstly, there is reason to assume that whether any particular perspective (and by extension: any text!) is felt in a particular way, say as cold or hot, depends in Nietzsche's view on the one who would come in touch with the perspective. In a sense then, coolness is relative. So the text of $H H$ will seem cool to many, ${ }^{23}$ but Nietzsche leaves the possibility open that his own perspective on his writing in $H H$ might be different. Secondly, there is the suggestion that the spiritual natures, among whom Nietzsche as author obviously counts himself, can be seen as useful,

23 Notice that Nietzsche in $E H$ does not write that the tone of the book is cool, but that it will be considered cool: "people will find the book" (Large 2007, 55); "man wird das Buch..." (KSA 6, 323). This later assessment reflects the reception of the work, which Nietzsche feared and anticipated in the passage in $H H$. 
as serving an important function: the image that they cast can serve the time by providing opportunities for self-reflection. It is near at hand to conclude that the image of the spiritual natures is reflected in their work. So if we now combine these two points and apply them to $H H$, we can conclude that Nietzsche's writing in $H H$ shows his own attitude and that many, particularly in his own time, will find the affective landscape reflected in his writing cold and uninhabitable, but that the interpretation of the mood of the text finally depends on the perspective of the reader. It is precisely this latter idea that allows for the possibility to use mood artistically to guide the reader to an affective perspective, through which the philosophical content of the work appears more understandable. But is there any suggestion in the passage that Nietzsche in fact would make such use of mood?

On the basis of this single passage, no far-reaching conclusions can be made. In fact, one might argue, given the centrality of the metaphor of mirroring in the passage, that the tone of the work is a simple reflection of the mood of the author. If indeed one would take Nietzsche to be striving towards the same objectivity as science, then one might conclude that the affective tone of the writing is nothing more than an unintentional result. The tone merely reflects the objectivity of science and there is no conscious effort on Nietzsche's part to lead the reader to the same state. On the other hand, the latter part of the passage with its talk of reaching for any means that could serve the purpose of cooling down and the clue that the coolness of the spiritual nature could do a service to a world that seems to be on fire, does suggest a more active role in guiding the reader. Though these two perspectives do not necessarily contradict each other, there is no denying that there is a marked tension between them. Put differently, it might be necessary to specify how "guiding the reader" should be understood, whether as an attempt at manipulation of the reader's emotions or as an open-ended communication that requires an active effort by the reader. There is also as of yet no clarity what this "cooling down" actually involves and what the resulting coolness consists of. Therefore, we will continue by discussing more evidence; specifically that evidence which Golomb relies on.

\subsubsection{Textual evidence about Nietzsche's use of mood}

There are only two aphorisms in $\mathrm{HH}$ where one can find the phrase "to put on ice" [auf Eis legen]; of which only one in the original publication of 1877, the other in The Wanderer and his Shadow. I will examine this latter aphorism first, as it plays an important role in Golomb's argument. The aphorism in WS, Upon the ground of disgrace, concerns the question how best to rid people of views one would rather see eliminated. Nietzsche explicitly chastises those who are not content to simply refute a belief but seek also to evoke a negative affective response in the person who holds the belief in order to prevent the belief from rising again. Instead of what he deems to be a 
counterproductive approach of throwing dirt on ideas, ${ }^{24}$ he recommends one to put beliefs on ice; if need be again and again. There is no suggestion that this would imply anything else (e.g. a different kind of affective manipulation) than simply sticking to a refutation of the beliefs that one wants to be rid of: if the belief arises again one should simply repeat the process patiently. The exhortation to put what one wants to set aside on ice again and again, certainly suggest a process of painstaking repetition. Such a reading gives a plausible explanation for the maxim that Nietzsche offers to conclude the aphorism: "One refutation is no refutation at all" (Handwerk 2012, 242; HH II, WS 211, KSA 2, 644). In this light it is hard to see how this aphorism could be used to support the claim that "Nietzsche preferred the method of freezing psychologization to rational disputation" (cf. Golomb 1989, 165). ${ }^{25}$ In any case: To take the passage (HH II, WS 211, KSA 2, 644) from the middle of The Wanderer and his Shadow, the last text to be added to $H H,{ }^{26}$ to support an argument concerning the method of the entirety of $\mathrm{HH}$, as Golomb does, is questionable to say the least. There is also a further problem with Golomb's interpretation that makes his statement doubly misleading.

Golomb's statement is doubly misleading, since it presupposes that the psychology that Nietzsche practices in $H H$ is somehow opposed to rational disputation and the refutation of beliefs. Here I take it that Golomb follows Nietzsche's comments in $E H$, where he declares that in $H H$ errors are not refuted, but frozen (KSA 6, 323). ${ }^{27}$ This reinterpretation does not capture all the uses of the word "refute" [widerlegen] in $H H$. In aphorism 9 of chapter one it is precisely the application of the psychological method that refutes metaphysics; when one has uncovered the faulty methods of

24 Cf. HH II, WS 211, KSA 2, 644. Nietzsche is undoubtedly himself guilty of this error of mocking the targets of his criticism, though this "vice" is not as pronounced in $H H$ as e.g. in the last works. 25 Another passage that Golomb refers to in support of the idea that the goal of Nietzsche's "psychologization" is to instill mood and that this is thoroughly distinct from rational refutation does contain a suggestion that a thorough mistrust in metaphysics would have the same consequences as if all metaphysics were refuted. However, the passage, read contextually, is really about Nietzsche wanting to challenge one to think what the consequences would be, if a sceptical sentiment would take hold of humanity. In other words: the aphorism is concerned with a hypothetical situation, not the method of $H H$ (HH I 21, KSA 2, 42-43; cf. Golomb 1989, 169).

26 WS was originally presented in 1880 as an independent work unrelated to $H H$ and only added to $\mathrm{HH}$ in 1886, together with Mixed Opinions and Maxims, to form volume two of the book (cf. Young 2010, 277).

27 Another instance that could be used to support Golomb's contention can be found in WS 82 (HH II, WS 82, KSA 2, 589). There Nietzsche takes to task those who think it is necessary to refute a party or religion, after one has left it. According to him, it is enough to see what brought one to the party or religion in the first place, what motivations held one there and finally what motivations drove one away. Here, Nietzsche seems to employ the term "refute" in a very strict sense; restricting its use to matters of "pure" Erkenntnis. 
reasoning that metaphysics relies on one has refuted metaphysics. ${ }^{28}$ It is certainly the case that Nietzsche seeks to replace metaphysical reasoning with historical and psychological reasoning, but this does not imply rejecting the value of rational disputation. In fact, Nietzsche takes the capacity to distance oneself from one's own thoughts, the ability to "put them on ice", as a prerequisite of disputation. The short aphorism 315 of book one boldly declares: "Requisite for disputing. - Anyone who does not know how to put his thoughts on ice should not head into the heat of battle." (HH I 315, KSA 2, 315) This short aphorism, the only one containing the phrase "put on ice" [auf Eis legen] in the original publication, expands and clarifies the notion of putting one's beliefs on ice. On the basis of it, one can surmise that one should not only learn to view thoughts one wants to be rid of from a distance; it is useful to be able to view even one's most cherished thoughts from the same distance. In the following, I will examine passages that spell out the ideal which forms the basis for this view.

In his discussion on the merits of "freezing psychologization", Golomb does refer to some passages in the originally published work that better serve his end (cf. Golomb 1989, 173-174). For Nietzsche, psychological observation can serve to ease the burden of life (HH I 35, KSA 2, 57). How does psychology serve this end? Golomb speaks of the effect of "psychologization" as a "cooling" down and refers to aphorism 56 of book one (HH I 56, KSA 2, 75; cf. Golomb 1989, 173). This topic certainly deserves a more thorough exposition than that provided by Golomb who contents himself with a simple reference to the aphorism. The aphorism, entitled Triumph of knowledge over radical evil, describes the benefits of the perspective open to one who has passed through the stage of believing in the metaphysical reality of evil and who on account of his experiences no longer desires much more from things than knowledge. Such a person finds peace easily, as having knowledge as his only goal cools him down. ${ }^{29}$ In itself, this single aphorism offers little more than a description of a particular path to inner peace, to freedom from illusions, albeit one might add that there probably is an autobiographical background to it. No farreaching conclusions to our questions can be drawn on account of it. There is however a more thorough discussion of the ideal of calm in $H H$ that has much to offer us; a passage which incidentally Golomb does not discuss.

The ideal of calm is more clearly spelled out in an earlier aphorism, aphorism 34 of chapter one; For reassurance [Zur Beruhigung], in which Nietzsche thematizes the

28 "hat man sie widerlegt" (HH I 9, KSA 2, 29). This use of the term resembles what Nietzsche writes about historical refutation [historische Widerlegung] in D (D 95, KSA 3, 86-87, cf. section 4.3 .3 of this study).

29 "the single goal that fully governs him, to know at all times as well as he possibly can, will make him cool and will calm all the savagery in his disposition" (Handwerk 1997, 56; HH I 56, KSA 2, 75). It cannot be emphasized enough that the removal of "savagery" is not to be understood as a removal of all powerful feeling. As we have already seen, "living for knowledge" crucially involves reflecting on one's feelings. 
effect of knowledge on the free spirit. He deceptively begins by asking a series of pessimistic questions that culminate in the question whether the quest for knowledge does not end in despair. He then cuts this pessimistic tirade short in order to declare that he believes the effect of knowledge to be a matter of temperament. Nietzsche surmises that the reaction he initially described was only one of many possibilities, and goes on to describe an alternative in which the confrontation and preoccupation with knowledge leads the way to a form of life freer from troubling affects. ${ }^{30}$ Such a reaction to knowledge requires a good temperament: "a stable, mild, and basically cheerful soul, a mood that would not need to be on guard against pranks and sudden outbursts" (Handwerk 1997, 41-42; HH I 34, KSA 2, 53-55). A liberated spirit with this kind of temperament would not rage at having once been bound. He would have to renounce much of what is commonly valued and be content to dwell in a free and fearless mood above customs and morality, living only for knowledge. This state Nietzsche conceives of as a joyful state, as he declares in a sentence that is crucial to our endeavour: "He is glad to share the joy of this state and he has perhaps nothing else to share" (Handwerk 1997, 41-42; HH I 34, KSA 2, 53-55).

Is this not the evidence we have been looking for? Is this aphorism not proof that Nietzsche tried to communicate a specific mood through $H H$ ? Does it not suggest that this mood is more important than anything else in the book, perhaps the only thing he has to communicate? Does it not imply that he wants to lead his readers toward this ideal? Not necessarily, and therefore the questions are worth examining closely and critically before jumping to conclusions.

First of all, one would have to assume that the state that Nietzsche describes is an autobiographical confession, and an honest one. Secondly, one would have to understand his words as a meta-commentary on $\mathrm{HH}$ and take them to mean that he seeks to share and transmit a certain mood to his readers through his writing. The first claim is problematic, but not indefensible. The main problem is whether one should identify the calm and joyful response as Nietzsche's own response to knowledge. One might claim that the latter alternative (good temperament - joyful mood) presented in the aphorism should not be mistaken for Nietzsche's own response as little as the first alternative (melancholic temperament - despair) should. ${ }^{31}$ Be that as

30 The key question here is how to understand Nietzsche's words of a life "more purified of affects" [von Affecten reineres Leben] (Handwerk 1997, 42; HH I 34, KSA 2, 53-55). As the aphorism shows, Nietzsche thinks that knowledge can both purify and weaken violent passions. The question is whether these two necessarily go together; whether purification always entails weakening. While Nietzsche seems unable to make up his mind in $\mathrm{HH}$, I think that the metaphor of distancing makes most sense of his statements. Nietzsche strives for a certain distance from his own passions, but this distance is itself an affective state; an all-enveloping mood. Be that as it may, it is certainly not the case that Nietzsche's ideal would be a life totally bereft of feeling, as the final part of the aphorism shows. 31 Marco Brusotti notes that Nietzsche's self-understanding only shines through indirectly in $H H$. Still he somewhat hesitantly concludes that Nietzsche in $\mathrm{HH}$ seems to count himself among those with a good temperament. Relevant evidence can be found in unpublished writings from the period in which Nietzsche attests to having a good temperament (Brusotti 1997, 176-177; see especially foot- 
it may, this objection can be seen as irrelevant as one might counter it by insisting that it is enough that Nietzsche holds out the calm response as an ideal. ${ }^{32}$ It stands to reason that Nietzsche would not want to lead the reader to his own possibly conflicted state of mind, but towards an ideal state perhaps more reflective of his "higher self". ${ }^{33}$ Though the possible difference between Nietzsche's ideal and his actual temperament is an interesting issue, it is my contention that it does not complicate the question of authorial intention in any significant sense. The difference between an all-too-human Herr Nietzsche and an ideal philosopher-author of the text dissolves when one recognizes that the latter can be reduced to the intentions of the human, all too human thinker. This difference does, however, raise the possibility of a dissonance between intent and achievement. I will return to this question at a later stage; for now it is time to move on to the second claim.

In lack of unambiguous evidence, there is greater reason to doubt the second claim, i.e. that the passage should be understood as a meta-commentary on $\mathrm{HH}$. Nevertheless, even the most sceptical interpreter should concede that the passage provides the best indirect evidence that can be found in the content of the book, besides that provided by aphorism 38. This is because it makes sense to understand the discussion of knowledge and responses to knowledge in the passage as directly related to the knowledge that Nietzsche's book contains - and the possible responses to the book. This analogy is not some far-fetched speculation, but follows from the recognition that Nietzsche's inquiries in $\mathrm{HH}$ generate precisely the kind of knowledge that is potentially tragic and that through $\mathrm{HH}$ the reader becomes acquainted with such knowledge. Let us provisionally accept the premise that the passage can be read in this way and see where it leads.

If one accepts the premise that the passage can be read as a meta-commentary on $\mathrm{HH}$, then there is still the problem of establishing that the passage shows that Nietzsche sought to communicate a specific mood to his readers. A close reading of the passage reveals that what the hypothetical free spirit gladly communicates is his joy at his calm state of mind. The free spirit can show his own joy in what he does, in his writing, but once again it is not clear if he seeks to lead the reader

note 319; cf. KGB II/5, Bf. 734). Brusotti notes further that this self-evaluation contrasts with the one in Daybreak, where Nietzsche practically admits that he has a melancholic temperament (Brusotti 1997, 178).

32 That Nietzsche indeed held a good, i.e. calm, lofty and joyful, temperament as an ideal in $H H$ can be backed up with textual evidence. This short aphorism can be considered typical: "Das Eine, was Noth thut. - Eins muss man haben: entweder einen von Natur leichten Sinn oder einen durch Kunst und Wissen erleichterten Sinn." (HH I 486, KSA 2, 317)

33 The idea of a "true self" or a "higher self" of aspiration plays a central role in Nietzsche's untimely meditations on Schopenhauer and Wagner (cf. Young 2010, 520). Young in his turn paid homage to this idea, and emphasized the importance of it to Nietzsche, by allowing it to structure much of his own biographical narrative of Nietzsche's life and aspirations. This hermeneutic is certainly justified from a biographical perspective, as it can hardly be denied that Nietzsche's life was a life of constant striving, despite the philosophical Nietzsche's protestations to the contrary (cf. KSA 6, 294-295). 
to the same attitude. The least that can be said about aphorism 34 is that if indeed the free spirit seeks to communicate a mood it would be primarily that of joy. This is quite at odds with the emphasis in Golomb's thesis that Nietzsche seeks to instill a cold mood of suspicion towards metaphysics, though admittedly the two should perhaps be seen as complimentary; i.e. as a union of joy and doubt. Yet on the basis of the whole of the passage in question, one might equally well support the thesis that Nietzsche does not seek to instill any specific mood in the reader through the philosophical content of the work, since how the reader responds to knowledge is in the end a matter of the temperament of the reader. Despite the solid textual foundation that it rests on, it is hard to content oneself with this last objection. This is not least because the philosophical content strictly understood, i.e. the statements contained in the passages, is not the only aspect that should be considered when discussing Nietzsche's use of mood in any of his works. We are here faced with a larger interpretative problem. There is a need to specify, how one conceives of Nietzsche's communication of mood in his writings; in specific texts understood as wholes as well as in single passages. The key question in this regard is not the abstract one whether Nietzsche merely holds out possibilities for contemplation or actively seeks to force the reader to inhabit an affective perspective. It is rather the problem of distinguishing where Nietzsche merely holds out possibilities for contemplation from those affects and moods that Nietzsche considers desirable and would have his readers open up to. Needless to say, no generalizations can be made on the basis of single passages and any credible interpretation must be contextual in the sense that it takes into account all evidence concerning Nietzsche's intentions.

We here seem to have reached the limits of the method that we have utilized thus far. Following the example of Golomb, we have drawn attention to and analysed passages in $\mathrm{HH}$ in order to find answers to our questions. No conclusive answers have been found. Golomb argued that Nietzsche uses mood to instill doubt in the reader, but on the basis of the contents alone, one might equally well support the thesis that Nietzsche's focus in $H H$ is more on analysing feelings than on manipulating them. However, not all evidence has been exhausted yet. It is quite curious and irritating that despite the emphasis he places on the role of mood in $\mathrm{HH}$, Golomb has nothing to say about the tone of the work. That Golomb does not go into a detailed discussion about the aphoristic form is not the problem. ${ }^{34}$ The question of tone is distinct from the question of form. Both questions concern style, but the question of tone is arguably primary in any discussion on the communication of mood. That is because no form is in itself an expression of a specific mood, though form can certainly facilitate the communication of affect. When I now ask about the tone of $\mathrm{HH}$, I refrain from

34 One can even question whether it is instructive at all to speak of aphorisms in the case of $H H$, even if Nietzsche himself spoke of the passages in the work using that term (cf. Franco 2011, 13). Hödl goes as far as to write of $H H$ as a work that is wrongly called a book of aphorisms (Hödl 2007, 152). Whatever the passages that make up $H H$ are called, I do not see how this stylistic choice would in itself reveal anything about Nietzsche's communication of mood. 
making any claims about authorial intention. That means that the approach is initially purely descriptive. It is my contention that an inquiry into tone that proceeds cautiously can deliver important if inconclusive results, and should not simply be rejected outright on account of its subjectivity.

\subsubsection{A general characterization of the tone of $\mathrm{HH}$}

What is the tone of $H H$ like? In $E H$, Nietzsche writes that one will find the tone of the book "clever, cool, perhaps harsh and mocking” (Large 2007, 55; KSA 6, 323). Does this assertion fully capture the tone of $\mathrm{HH}$, or is there more to be said about the matter? Does the tone not guide the reader to the joyful ideal of lofty calm and inner peace? Does it not also open up a mood of suspicion for metaphysics? There would at least have to be some detectable glimmer of joy in the text for one to take seriously the claim that the free spirit enjoys his viewpoint and seeks to communicate his joy (HH I 34, KSA 2, 55). To point this out and to ask such questions need not mean denying that the tone of $\mathrm{HH}$ is best described as cool, but it does mean adding something to the description. In other words, there is no reason to accept $E H$ as dogma, even if it serves well as a starting point for an inquiry that aims for a full picture of the tone of $\mathrm{HH}$.

Before trying to answer these questions, it has to be asked whether and in what sense $H H$ forms a whole. The scholarly consensus is that the text of $H H$ as presented in the KSA does not form a whole, though it should be mentioned that Paul Franco has sought to argue against the consensus and for the coherence of the entire work (Franco 2011, 14-16). ${ }^{35}$ A quick consideration of the two texts added to $H H$ in 1886 should be enough to cast aside any doubts about the consensus view. On this issue, I share Julian Young's judgement. Young calls Mixed Opinions and Maxims (1879) "a fairly random collection of bits and pieces that didn't find their way into the main work", but recognizes that it "shares the same theoretical outlook" as $H H$ (Young 2010, 275). It should be added that not only does the theoretical outlook remain largely in tune with the earlier books; so does the tone. The Wanderer and his Shadow (1880), on the other hand, is quite different both in tone and content (cf. Young 2010, 277-289). ${ }^{36}$ These considerations support the consensus view, and

35 I raise initial doubts about Franco's position in the discussion on the "problem of culture" in section 4.1.2.

36 The ideal of living only for knowledge seems to have been supplanted by an ideal of living for joy. Perhaps it would be best to say that the ideal of living for joy has been superimposed on the former ideal, which was already characterized as a joyful one. The solitary Freigeist has the right to say "dass er um der Freudigkeit willen lebe und um keines weiteren Zieles willen; und in jedem anderen Munde wäre sein Wahlspruch gefährlich: Frieden um mich und ein Wohlgefallen an allen nächsten Dingen." (HH II, WS 350, KSA 2, 702) The focus is no longer on scientific knowledge but on the "nearest things" that provide the means to joy (cf. Brusotti 1997, 134). Consequently, there is also a change in the char- 
allow us to restrict our focus to the original 1878 publication, which includes those chapters that are of greatest relevance to us.

At a first glance, volume one of $H H$ is remarkably balanced compared to some of Nietzsche's later writings, even if one excludes the Antichrist and Ecce Homo from one's survey. Whereas there is no escaping the impression that the author of the later works is passionately concerned about the things he writes about, this work mostly does suggest that the author dwells far above the things he writes about, gazing down at them from a distance. There is also a joy present in the work that at times becomes very explicit (e.g. HH I 291 and HH I 292, KSA 2, 234-237), but mostly stays in the background. To be absolutely clear, I am not denying that one might be able to detect slight changes in tone between the chapters. More importantly, however, not everything within the most serious chapters of volume one is that cool and dispassionate. Is there not also uneasiness and irritation? This is arguably the case in the chapter on the state but it is especially troublesome in the chapter that is centred on the question of religion, which I will now revisit. The reason for focusing on the chapter on religion is that the role of politics and the state in Nietzsche's philosophical projects stands in question, so much so that now and again the question is asked, whether Nietzsche can be considered a political thinker at all. That Nietzsche is an important thinker on religion is beyond any doubt, and as has been mentioned some even go as far as calling him an essentially religious thinker (cf. Young 2006, 201). That is not to say that nothing could be gained from an analysis of the tone in which Nietzsche writes on the state and politics; in fact, such an investigation could reveal issues obscured by a one-sided focus on the content of what he has to say. Here, anyhow, it is justified to limit the discussion to the topic of religion and those parts of Nietzsche's text that are of direct relevance to the questions of this study.

\subsubsection{The unbalanced tone of chapter three: The trouble with the ascetic}

The chapter The Religious Life is not that balanced despite the rational explanatory schema that underlies it. This can be shown by careful consideration of Nietzsche's treatment of the Christian ascetic in aphorisms 136 to 144, the greater part of which exhibits a tone that is best described as feverish. The starting point of Nietzsche's discussion, and by Nietzsche I here and in what follows obviously refer first and foremost to the persona created within the text of $\mathrm{HH}$, is to be found in what seems to be a thinly veiled irritation with the fact that science had as of then not been able to provide an explanation for asceticism. Nietzsche takes this task upon himself; the task to cast a scientific light on the nature of asceticism. Because he explicitly men-

acter of the joy that is aspired to, as the emphasis is no longer on the absence of disturbing passion but on a rejoicing in the "nearest things". Arguably, the tone of WS reflects this change. 
tions the idea of science as a reflection of nature [Nachahmung der Natur] in the passage (HH I 136, KSA 2, 130), one would expect a treatment in tune with the dispassionate spirit of objective science (cf. HH I 38, KSA 2, 61-62). We have already established the underlying rational schema which structures Nietzsche's analysis; his method of explaining complex phenomena through the elements that make them up. Now we focus on the manner in which he presents his analyses, how he puts the schema into his text. This is an important question, for what he provides is far from a dispassionate analysis. Indeed, his "analysis” is more akin to an exorcism, in which he doesn't spare words of contempt.

Nietzsche first fixes his eye on how ascetics turn their spite and wrath against themselves, and gives a few examples that are described with a marked scorn to illustrate his point. Without justifying his interpretation he suddenly exclaims: "This shattering of oneself, this mockery of one's own nature, this spernere se sperni of which religions have made so much is really a very high degree of vanity", adding: "The whole morality of the Sermon on the Mount fits in here" (Handwerk 1997, 105; HH I 137, KSA 2, 130 -131). The impression is that the author seeks to shock the reader through this statement, which in its own time could only have come across as mockery, but the absence of any justification for his conclusions is quite telling.

Nietzsche deals similarly with a related component of asceticism and sainthood, charitable self-denial. Acting for the good of others, even when it might be detrimental to others, is not limited to saints, but the saint has made it his trademark. Such acts Nietzsche explains with reference to the feeling that accompanies them and results from them. His treatment is so cursory as to be unsatisfactory: it is hard to escape the impression that what matters to Nietzsche here is not the evidence but arriving at the conclusion: "It is therefore really only the discharge of his emotion that matters to him" (Handwerk 1997, 106; HH I 138, KSA 2, 131-132). There is really no argument as to in what sense the ascetic differs from anyone else in this regard, only the assertion that the ascetic in fact tries to make his own life easy by renouncing care about all that is mortal (HH I 139, KSA 2, 133).

In the following aphorism, Nietzsche explicitly connects the ascetics' purported lust for emotion for its own sake with weakness of the nerves. It serves to counter the boredom to which their own spiritual laziness and their self-imposed submission under a foreign will has led them. (HH I 140, KSA 2, 133-134). The choice of words in this aphorism, as in selected parts of the broader discussion, does speak of a contempt that is more powerful than the ideal of scientific calm. The next aphorism exhibits the same vehemence: through convoluted sentences Nietzsche moves from a discussion about the sexual impulse to generalizations about the nature of the feeling of sinfulness in order to finally suggest, but without explicating how, that there is a historical connection between Christianity and societal decadence. If there is one thing that deserves specific attention it would be that Nietzsche seems particularly incensed about what he takes to be the use to which psychology was put to by ascetics. In the hands of ascetics, psychology was used to make people feel sinful. Yet instead of focusing on explaining how such a use of psychology could 
be effective in the first place, or what use of psychology would be preferable, Nietzsche simply focuses on complaining about how ascetics chastise all that is natural (HH I 141, KSA 2, 134-137).

In a final attempt to reassure that there is nothing special about ascetics, Nietzsche asserts that the world-historical importance of those deemed holy is not to be found in themselves, but in the fact that they are deemed holy by people. In Nietzsche's own words, the saint matters not because of what he or she is, but rather because what he or she means. (HH I 143, KSA 2, 139)

In a peculiar twist, the last aphorism of The Religious Life, which also finishes off the discussion on ascetics and saints, seems to recover at least something of the calm, objective spirit that Nietzsche associates with science. It is almost as if he would be startled by and recoil at what he has written in the preceding pages. Recognizing that the picture he has painted of the saint, which he says has painted according to the average of the type, can be contrasted with presentations that produce a more pleasant response, he nevertheless proceeds to defend his approach (HH I 144, KSA 2, 139). This defence is not without irony, and it does not suggest that Nietzsche would recant anything. Indeed he does not. He merely relativizes his take on ascetics by adding that his explanation does not take into account singular exceptions to the rule, exceptions which he suggests could be viewed in a more sympathetic light. The big difference to the preceding passages is in the tone, which is once again balanced and even charitable, while simultaneously suggesting that the author gazes down at the issue from an ironic distance. The ironic tone shines especially clearly through the text when Nietzsche mentions the founder of Christianity as being one of those exceptional creatures whose delusions cast streams of light over their entire character. Quite aware that the notion of the founder of Christianity being delusional was still considered scandalous by many in his day, Nietzsche adds that one should not judge him too harshly for his delusion, since antiquity did not lack its fair share of sons of God (HH I 144, KSA 2, 139-140).

This recovery of tone in the final aphorism does not change the overall impression that an explanation of the elements that ascetics and saints are made of, such as self-denial and self-hatred, is only of secondary importance, the attack against them primary. Most of the text on ascetics and saints expresses an irritation, which does not suggest that the author would be above all of that he writes about. There is more here than the irritation of the reader and more than what is captured in the quip in $E H$ that one might find the tone "harsh and mocking" (KSA 6, 323). Nietzsche's treatment of the ascetic is cursory and forced; passionate, not calm. What are we to make out of this? One fruitful alternative is to point out that Nietzsche might not seriously strive to be dispassionate, and that what is more important is his desire to express a distance. There is certainly something to this explanation, as Nietzsche very vehemently seeks to distance himself from asceticism. Notwithstanding the passages in question, Nietzsche does on the whole manage to maintain a tone that expresses a certain aloofness, a distant joy, throughout $\mathrm{HH}$. 


\subsubsection{The ideal of calm and the mood of $\mathrm{HH}$}

To conclude, Nietzsche's writing in $H H$ manifests a mood of distanced suspicion in metaphysics, a mood that at times rises to become lofty and joyful. It is also the case that it is accompanied by a more agitated mood of irritation with metaphysics (and religion, morality, as well as the state of culture) that now and again gains the upper hand. This contrasts with Nietzsche's own later assessment that a nobility of spirit always has the upper hand in the work. In $E H$ he writes: "A certain intellectuality of noble taste seems to be continually keeping the upper hand over a more passionate current beneath it." (Large 2007, 55; KSA 6, 323) To me it seems that Nietzsche, given how he presents himself in $\mathrm{HH}$, can be said to be unable to fully keep his passion in check and to live up to his ideal. Nevertheless, the later admission that there is a passionate current at work in $\mathrm{HH}$ is already an important concession and an indication that one cannot view the work solely through the ideal of distance and calm. The ideal of calm is problematic.

That Nietzsche declares a state of mind akin to apatheia (Brusotti 1997, 228) a personal ideal in $\mathrm{HH}$ does not necessarily imply that his writing expresses that ideal fully. More disturbingly, one might from within Nietzsche's philosophy even question whether this need for peace is not a symptom of something else. This, I would argue, is precisely the question that Nietzsche asks of himself in the years following the 1878 publication. The claim that there is more to the tone of $H H$ than calm, to which we arrived through the analysis of Nietzsche's treatment of asceticism, can be supported by earlier evidence than that provided by his description of the tone in $E H$. Already during his free-spirit period, Nietzsche comes to realize that he is in the grips of a violent passion. He comes to see that his preoccupation with knowledge is at odds with the ideal of calm, as this preoccupation is itself the result of a passion. This passion he dubs the passion for knowledge [die Leidenschaft der Erkenntnis] (Brusotti 1997, 13). ${ }^{37}$

This serves as a reminder of an issue, which cannot be emphasized enough: Nietzsche's self-presentation, his own interpretation of his texts, has to be challenged and weighed against all evidence available to scholarship. For example, when Nietzsche writes in the 1886 foreword to $H H$ II about the whole of $H H$ that it has "something of the almost cheerful and inquisitive coldness of the psychologist" (Handwerk 2012, 5; KSA 2, 371), ${ }^{38}$ we can agree but note that this something does not

37 According to Brusotti, the first reinterpretation can be dated to summer 1880 (Brusotti 1997, 640). See also Brusotti's chapter "Die neue Leidenschaft setzt sich durch" (Brusotti 1997, 168). I have suggested, that the seeds of this "reinterpretation" are already present in the first version of $\mathrm{HH}$. Therefore, it is not so much a reinterpretation as a rationalization in a specific direction. This rationalization then leads Nietzsche to disengage the ideal of distance from the ideal of calm, which is a very important step towards $D, G S$ and the arrival of Zarathustra.

38 "Etwas von der heiteren und neugierigen Kälte des Psychologen" (KSA 2, 371). 
completely express the mood of the work. ${ }^{39}$ When he goes on about the things discussed in $\mathrm{HH}$ as already then having been behind him and below him, one can calmly observe that this is simply not the case as he returns to the very same problems of metaphysics and religion in his later writings. To mention but one example, one can think of the relation between science and asceticism, which gains a far more thoroughgoing treatment in The Genealogy of Morals. Such discrepancy gives rise to a new critical question that must be taken into account by scholars concerned with Nietzsche and mood. Given that Nietzsche aspires to communicate mood, how well does he succeed? Now one might object that there is no reason to raise such a question at all, or at least not at this point. The critic can point to the fact that in the case of $\mathrm{HH}$, it has not been possible to establish the intention of the author with any certainty. One might therefore conclude that the question to what extent Nietzsche succeeds to communicate mood is superfluous as the question itself rests on a too shaky foundation. That conclusion would be as premature as the question, because there is still one category of evidence that has not been examined yet and which can help solve the problem concerning authorial intention; namely Nietzsche's notes and letters.

\subsubsection{Evidence about Nietzsche's use of mood in $\mathrm{HH}$ from his notes and letters}

From the period surrounding the original publication of $H H$, spring-summer 1878, there is a very short yet extremely suggestive notebook entry. ${ }^{40}$ It is the metaphor of mountain air [Höhenluft], which makes this note so interesting and so deserving of attention. After all, it is precisely this metaphor that Nietzsche employs in $E H$ to characterize his philosophy; and specifically what his writings communicate (KSA 6, 258-259). Already in this early note, Nietzsche understands his own philosophy as a philosophy of mountain air. Substantially, he establishes an analogy between those who seek out the alpine air of the Engadine in search of a cure for their ailments and those "patients", presumably his readers, whom he would send to his own air; to the heights of his philosophy. The implication is that his work has a therapeutic aim. This is not to say that a therapeutic aim would be the only aim of his philosophizing at this stage, but that he clearly sees his thinking as having therapeutic potential. So what is the illness that his patients suffer from and who are the patients? Given Nietzsche's preoccupations in the period and considering the content of $\mathrm{HH}$, it is safe to say that whatever one calls the disease its main symptoms are false interpretations of the human predicament in general and metaphysical in-

39 "Auf ihm, als einem Buche 'für freie Geister', liegt Etwas von der beinahe heiteren und neugierigen Kälte des Psychologen, welche eine Menge schmerzlicher Dinge, die er unter sich hat, hinter sich hat, nachträglich für sich noch feststellt und gleichsam mit irgend einer Nadelspitze fest sticht” (KSA 2, 371). 40 "Ich sehe die Leidenden, die in die Höhenluft des Engadin sich begeben. Auch ich sende die Patienten in meine Höhenluft - welcher Art ist ihre Krankheit?” (NL 1878, 27[21], KSA 8, 490) 
terpretations of all human things in particular. One might conclude that all those for whom he writes are potential patients, but the question is whether Nietzsche did not have a more specific group in mind; namely the Wagnerians. In a remarkable passage of $E H$, Nietzsche seems to recall that his first discovery of and initial fascination with the air of the heights coincided with his turn away from all that which the word Bayreuth signifies, as he explicitly opposes the Wagnerian swamp with the air of the Engadine, where one dwells "6000 feet above Bayreuth".41 That there indeed is an intimate connection between the anti-ideal, or idealization of the air of the heights, and his Bayreuth-crisis finds support from Nietzsche's letters, in which he mentions this mountain air. These letters shed much light on Nietzsche's intentions and leave little doubt that he sought to guide his readers to this experience.

The first letter that merits attention is one that Nietzsche wrote to Heinrich Köselitz on 31 May 1878. The focus of the letter is on the reception of his latest work. As $H H$ philosophically meant a decisive break with Schopenhauer, it personally meant an irreparable break with Wagner and his followers. In this sense, Nietzsche contrasts the reception of $\mathrm{HH}$ in the Wagnerian circle with that of Rée and Burckhardt. Whereas the Wagnerians responded to his turn against Schopenhauer with lack of understanding and outright distaste, a response Nietzsche likens to excommunication, the latter two scholars reportedly responded with joy (KGB II/5, Bf. 723). This latter response, the letter reveals, has given him reason to think about the preconditions for his work having an impact. Specifically, he writes, the response shows what kind of readers are ready for his work. ${ }^{42}$ What makes the letter even more interesting to us is that Nietzsche not only hints at what kind of reader would be the ideal reader of his work, but also reveals what kind of a response he considers ideal. This he does by imagining what the effect of the book would be upon one who would spend as

41 In the passage, Nietzsche praises his purported ability to bring forth the best in those who come close to him: "Whatever the instrument - even if it is as out of tune as only the instrument 'man' can go out of tune - I would have to be ill not to succeed in getting something listenable-to out of it. And how often have I heard from the 'instruments' themselves that they have never heard themselves sounding like that... The finest example of this was perhaps Heinrich von Stein, who died unforgivably young: once, after carefully obtaining permission, he turned up in Sils-Maria for three days, explaining to everyone that he had not come for the Engadine. For those three days it was as though this splendid man, who had waded with all the impetuous naivety of a Prussian junker into the Wagnerian swamp ( - and the Dühringian one, too!), had been transformed by a storm-wind of freedom, like someone who is suddenly raised up to his height and given wings. I always told him it was the good air up there that was doing it and everyone was affected in the same way - we were not 6,000 feet above Bayreuth for nothing - but he wouldn't believe me...” (Large 2007, 11; KSA 6, 269-270) The comedy of this hyperbolic passage is only heightened by Nietzsche's deliberate mixing up of the influence of the physical air of the heights with that of his own presence as a kind of being of the mountain air. He wants to be understood as one with the elemental forces of the alpine nature.

42 "wie die Menschen beschaffen sein müßten, wenn mein Buch eine schnelle Wirkung thun sollte" (KGB II/5, Bf. 723). How does one create people with good temperament, "wie erzeugt man Menschen mit gutem Temperament?", Nietzsche also asks in a note, which was written in the summer of 1879 (NL 40[27], KSA8, 583). 
much time with it as his friend and editor Köselitz: new thoughts, new feelings and a stronger mood, as if one would find oneself in lighter mountain air. ${ }^{43}$

Directly after mentioning this powerful mood that he associates with the air of the heights, Nietzsche expresses his joy at hearing Rée's reaction to the book; namely that it put him in a mood of productive enjoyment [Stimmung produktiven Genießens] (KGB II/5, Bf. 723). Nietzsche then explicitly affirms that to inspire readers to think independently and become productive was the best he hoped to achieve. Not only does the letter testify of the importance he attached to enabling a specific mood [Stimmung], it further points to mountain air, the air of the heights, as the key metaphor for a more encompassing affective ideal. Importantly, the letter suggests that the ideal is not something that the reader can or should slavishly submit to. It is not a mood that can be forced upon a reader. It is rather a mood that frees thinking. As such, it is made up of feelings of independence, of distance, of being above. Because of this, it requires a lot from the one who would inhabit it. Not least does it presuppose what Nietzsche calls a good temperament. We can nevertheless now conclude that his insistence that the effect of knowledge (cf. HH I 34, KSA 2, 53-55), varies according to temperament doesn't exclude the attempt to communicate a specific mood. For there are individuals who are ready for this communication, and there will perhaps be more in the future. It is for these free spirits that Nietzsche claims to write, as the subtitle of $H H$ states that it is a "book for free spirits", and it is they who will gain from being immersed in the fresh air of the heights.

The contention that Nietzsche indeed had a specific "ideal" in mind finds further support in Nietzsche's reply to a letter by Erwin Rohde, which he sent shortly after receiving Rohde's letter on 16 June 1878 (see KGB II/5, Bf. 727). This letter testifies of the same concern with reception as the letter to Köselitz. One could even go so far as to claim that it shows Nietzsche desired to control the way his work was read, since he gives instructions to guide the interpretation. Justifiably fearing that his friend's sympathies are still with the Wagnerians, he bids Rohde to at least take a look at the book and read some passages, in the hope that he might eventually come to grasp it as a whole. Why would it be so important to grasp the work as a whole? Nietzsche insists that if Rohde were to see the whole as a whole he would finally be able to understand the experience that grounds the work, and thus he could take part in the joy of the author. In fact, Nietzsche speaks of this experience as the highest joy that he has thus far felt. In the process, he expressly forbids his friend to ponder about how the book came to be. ${ }^{44}$ After distancing his work from

43 "Ja, wenn man soviel eindringenden Ernstes und auch soviel Zeit einem solchen Erzeugniß weihen wollte wie Ihre Güte gethan, so käme wohl etwas dabei heraus: nämlich Neues an Gedanken und Gefühlen und eine kräftigere Stimmung, wie als ob man in leichter gewordene Luft der Höhe gerathen sei.” (KGB II/5, Bf. 723)

44 “Grüble nicht über die Entstehung eines solchen Buches nach, sondern fahre fort, dies und jenes Dir herauszulangen. Vielleicht kommt dann auch einmal die Stunde, wo Du mit Deiner schönen konstruktiven Phantasie das Ganze als Ganzes schaust und an dem größten Glücke, das ich bisher genoß, teil- 
Reé, Nietzsche returns to mood at the end of the letter with an evocation of this "highest feeling of joy". He expresses the wish that Rohde could feel what he feels since having established an ideal of life. And what is this ideal? That is left unspecified, but he importantly associates it with the fresh air of the heights and a mild warmth. ${ }^{45}$ Perhaps it is nothing other than the mountain air-experience itself, translated into a philosophical mode of life. In $H H$, this ideal is to "live for knowledge". The least that can be said is that the ideal in question leaves metaphysical ideals and associated experiences behind in favour of a more intense experience of life.

It is quite telling that when Nietzsche in a letter to Mathilde Maier, an acquaintance from the Bayreuth-circle, tries to justify his attack on metaphysics, to make it understandable, he does so with reference to the mountain air [Höhenluft] that he dwells in. The most striking claim of the letter is the assertion that this new mood allows him to be free of vindictiveness. Instead, he associates the air of the heights with a mild mood [Stimmung] towards all those humans who still live in the haze of the valleys; a rather thinly veiled reference to all those such as the Wagnerians, who are in the grips of metaphysical philosophy. Furthermore, he writes that this new mood allows him to be far closer to the Greeks than ever before and truly live the pursuit of wisdom. Again, as in the letter to Rohde, he emphasizes the authority of his feeling: if only Mathilde could through his words understand [nachempfinden] the experience of his change, she would wish to experience something similar. Finally, he foresees that he will have to dwell alone, in order to one-day return as a philosopher of life. (Cf. KGB II/5, Bf. 734.)

Nietzsche does not only speak in this way, emphasizing mood, because he would believe that the recipients of his letters value feeling above all. There is much more reason to believe that Nietzsche honestly tries to speak if not of a decisive change in his life then at least of something he considers of great value. Together, these letters indicate that he had fixed his eyes on a specific affective ideal and wanted to communicate it. However, all of the letters were written after the publication of the finished volume. Therefore, their importance could be challenged by claiming that they do not say that much about the philosopher's intentions when writing $H H$ as much as of a changing interpretation of the work post-publication. Besides that, this purported ideal of mountain air remains obscure; the best that has been provided are rather vague phenomenological descriptions. Both of these objections are worth considering, but they do not present a serious challenge to the plausibility of the thesis advanced here. Much can be gained by considering Nietzsche's first use of mountain

nehmen kannst." (KGB II/5, Bf. 727) The real reason for this plea is revealed in the following paragraph, in which Nietzsche insists that the philosophical outlook presented in $H H$ is his own and not that of Reé; an outlook that he embraced independently before becoming better acquainted with his new friend in autumn 1876 (Ibid.).

45 "Fühltest Du nur, was ich jetzt fühle, seitdem ich mein Lebensideal endlich aufgestellt habe - die frische reine Höhenluft, die milde Wärme um mich - Du würdest Dich sehr, sehr Deines Freundes freuen können. Und es kommt der Tag." (KGB II/5, Bf. 727) 
air [Höhenluft] as a metaphor in a note from a notebook dated to the end of 1876 to summer $1877 .{ }^{46}$ Though the metaphor is not described in any more detail in this note, the note provides important clues for interpretation. Even if the ideal mood were phenomenologically as distant and unaccessible to the reader as before, the way Nietzsche ties his discussion to a historical situation points directly toward what Nietzsche had in mind. In a situation where religious notions of God, sin, salvation and the like have been discarded, he here claims, a passing sickness will require replacements for the lost attachments. When he goes on to speak of philosophies that serve as "transitional climates" for those not yet ready for pure mountain air, it is near at hand to think of metaphysical philosophies such as Schopenhauer's, in which religious evaluations and intuitions are presented as rational philosophy. Be that as it may, it seems clear enough that Nietzsche himself wants to show the way onward from "transitional climates". In this sense, the note can be used to understand how Nietzsche situates his own philosophical project historically. In $\mathrm{HH}$, Nietzsche deals coldly with those who would satisfy religious needs through philosophy and put modern concepts in the place of God. Instead of serving as a transitional climate, the point of $\mathrm{HH}$ is to guide those who are ready toward the true mountain air. In this sense, $H H$ is but the first necessary step on a journey, and Nietzsche is clearly aware of this.

This applies even more so to this first mention of the metaphor. Nietzsche even seems at a loss to describe the mountain air at all. The analogy to the Greeks doesn't lead anywhere. A plausible way to make sense of this lack of precision from within Nietzsche's own thinking is to assume that this is precisely because the experience is something new, something young. It does not derive from the past, but speaks of the future. The new feeling, the new affective ideal is not something always and anywhere accessible, but is tied to the historical situation, which makes it possible. This first metaphorical use puts the eponymous experience into the historical context of the decline of Christianity, which Nietzsche is a few years thereafter to thematize as the death of God. Although the note itself doesn't provide a phenomenological description of the experience, it allows us to read Nietzsche's philosophical project from $\mathrm{HH}$ onward as a drive toward a real engagement with and proper appreciation of mountain air. In this interpretation, Nietzsche's message is that the philosophy of the future will be characterized by a new kind emotional foundation. Against this background, the objection that the concept is vague loses its edge. What is to be ex-

46 "Geistige Übergangsclimata. - Wir haben uns freigemacht von vielen Vorstellungen - Gott ewiges Leben vergeltende jenseitige und diesseitige Gerechtigkeit, Sünde Erlöser Erlösungsbedürftigkeit -; eine Art vorübergehende Krankheit verlangt einen Ersatz an die leeren Stellen hin, die Haut schaudert etwas vor Frost, weil sie früher hier bekleidet war. Da giebt es Philosophien, welche gleichsam Übergangsclimata darstellen, für die, welche die frische Höhenluft noch nicht direct vertragen. - Vergleiche, wie die griechischen Philosophensekten als Übergangsklimata dienen: die alte Polis und deren Bildung wirkt noch in ihnen nach: wozu soll aber übergegangen werden? - es ist wohl nicht gefunden. Oder war es der Sophist, der volle Freigeist?” (NL 1876-77, 23[110], KSA 8, 442) 
pected of Nietzsche is not an exhaustive description but an engagement with this experience in his writings. On account of the evidence, one can conclude that Nietzsche for the first time sought to express this idea and ideal of mood in $\mathrm{HH}$. As an expression, it must perhaps be deemed incomplete and unsatisfactory, but then again $\mathrm{HH}$ was not the last time Nietzsche sought to express his ideal.

\subsubsection{Conclusion}

The critical engagement with Jacob Golomb's work has provided a clear view of the methodological problems involved in questioning Nietzsche's use of mood. The most important lesson has been that it is crucial to reconstruct Nietzsche's intentions and to interpret the affective dimension of his writings in the light of his projects. In this regard, the case of $\mathrm{HH}$ has shown that Nietzsche's letters can provide invaluable evidence when it comes to understanding what Nietzsche is trying to achieve through his writings.

In $\mathrm{HH}$, Nietzsche sought to communicate the experience of a crisis, which culminated in finding a new affective ideal. This intention is also reflected in the tone of the work, which is for the most part distant and cool yet simultaneously joyful. That Nietzsche has not fully recovered from or rather overcome his crisis is also apparent from passages which betray an irritation that is hard to reconcile with what Nietzsche writes of the new ideal. Nevertheless, Nietzsche's criticism of religion in $\mathrm{HH}$ is misunderstood if it is read only as a negative rejection of religious feeling. It is much more fruitful to recognize that Nietzsche admits the value of religious feelings, because reflection on such feelings has allowed him to find the way toward a new affective ideal. In other words, Nietzsche's destructive criticism is to be understood through his productive intention. In this regard, one can indeed conclude that the philosophical content of $\mathrm{HH}$ can be understood better, when one takes account of the role that mood plays in the work. As to Nietzsche's ideal mood, there are signs in $H H$, but especially in the letters, that Nietzsche understood the engagement with the new experience to be a momentous task. This idea of a task most probably contributed to Nietzsche's decision to leave his Basel professorship and to seek the solitude of the mountains, as he suggests in $E H$ (KSA 6, 324-326). The question is, to what extent Nietzsche's understanding of the air of the heights changes over the years, and how it influences his writings. This is the question for the following chapters. For now it must suffice to note, that there is a passage in The Wanderer and his Shadow, which strongly suggests that when Nietzsche from now onwards contemplated the question of style, it was primarily as a question concerning the communication of mood:

88. Instruction in the best style. - Instruction in style can, on the one hand, be instruction on how to find the expression that will let us convey any mood to the reader and hearer; or else instruction on how to find the expression for a human's most desirable mood, the one that it is there- 
fore most desirable to communicate and convey: the mood of a human who is moved from the depths of his heart, spiritually joyful, bright and sincere, someone who has overcome his passions. This will be instruction in the best style: it corresponds to the good human being. (Handwerk 2012, 197; HH II, WS 88, KSA 2, 593 ${ }^{47}$

\subsection{Religion and emotion in Daybreak}

Commentators who focus on religion have not had much to say about Daybreak. A notable example is Julian Young who devotes only $1 \frac{1}{2} 2$ pages to $D$ in his comprehensive overview study of Nietzsche's philosophy of religion (Young 2006, 86-87). The most likely reason for this neglect is that $D$ is often considered a transitional work and nothing more when it comes to the criticism of religion. This judgement is understandable; $D$ certainly is a transitional work. Still, it is not merely a transitional work. It is much more because of its foundational importance to Nietzsche's mature psychological thinking, which is comparable to that of $H H$. Not only does Nietzsche here present that possibility of interpretation that has led to the debate about his "drive psychology", his ideal mood is also crystallized. Therefore, it is near at hand to infer that a second reason for the neglect is that the relevance of Nietzsche's psychological thinking for his criticism of religion has been underestimated. In no way do I thereby intend to challenge the obvious fact that the main focus of the work is on moral prejudices as the subtitle suggests. Indeed, the published work is restrained in its focus and surprisingly so when compared to other works of Nietzsche (think of $H H, G S$ etc.). But then again, moral prejudices are inextricably tied to moral feelings and the history of religion, which makes both affectivity and religion central concerns of the work. As I have already dealt with Nietzsche's thinking on affectivity in $D$ (see chapter 3), I will here limit the discussion to those aspects which are of greatest relevance for understanding his criticism of religion. The discussion is guided by the conviction that carefully taking account of the development of Nietzsche's thinking as expressed in the published work is necessary in order to understand what he sought to achieve in his next work, in GS, and with the statement that God is dead which is found therein. I will therefore begin by examining the concerns that guide his treatment of religion in $D$, as well as the most important psychological statements, and then move on to the question concerning Nietzsche's possible "use of mood" in the work.

47 It is interesting to note that Nietzsche in this aphorism opposes mood [Stimmung] and [Leidenschaft] in the sense that one still dwells in mood after one has "overcome" all passion. While this single aphorism from WS should not be granted any special authority, it fits the interpretation that Nietzsche never sought to free himself from all feeling. 


\subsubsection{The problem of religious decline}

The period between the publication of $H H$ and $G S$ is one in which there are important developments in Nietzsche's thinking on affectivity that directly impact his thinking on religion. These developments, which more specifically concern the consequences of religious decline, have been discussed extensively by Marco Brusotti. Since his magisterial study Die Leidenschaft der Erkenntnis (1997) is not as well known in Anglophone scholarship as it should be, it is necessary to give a very short summary of one aspect of his research which is of direct concern here. The lasting value of this study is to have convincingly shown that Nietzsche was preoccupied with religious decline in the years following the publication of $\mathrm{HH}$. In the notes from the period, Nietzsche goes as far as to envision a substitute "religion", an atheistic new religion [religion nouvelle] (NL 1880 -81, 8[94], KSA 9, 402-403) or a religion of boldness [Religion der Tapferkeit] (NL 1880 -81, 8[1], KSA 9, 384), though at other times he explicitly states he does not wish to see the rise of an atheistic religion even if he considers such a development probable (NL 1880, 7[111], KSA 9, 341). Brusotti's interpretation of this preoccupation is nevertheless far from unproblematic. According to Brusotti, Nietzsche fears that he has underestimated the consequences of secularization. ${ }^{48}$ As a response to secularization, which here refers specifically to the crisis of the affects and ideals that have sustained Christianity in Europe, Nietzsche struggles to find a proper affective response. In trying to explain why Nietzsche thinks that the response to secularization has to be above all affective, Brusotti relies on Nietzsche's idea that the fight against Christianity, which is indebted to a religious passion for truth, had until then produced a productive affective tension in the European spirit. As a consequence of a serious decline, this tension might disappear and the consequence would be a catastrophic form of nihilism (Brusotti 1997, 647). While this interpretation is suggestive, it is hardly plausible as it relies more on Nietzsche's later remarks about such a tension (cf. BGE Foreword, KSA 5, 12-13) than on the scattered remarks that Nietzsche makes about such an affective tension in the period surrounding the publication of $D .{ }^{49}$ On the basis of the available evidence, all that can be said about the matter with any certainty is that Nietzsche thinks the proper response to secularization must avoid the danger of a general weakening of affect inherent in the process (cf. Brusotti 1997, 195-212; cf. 385 and 647).

There is another way of reading Nietzsche's preoccupation with religious decline, in the light of which Nietzsche's affirmation of affect is more understandable. On this reading, Nietzsche sees religious decline not only as a threat but as an opportunity. The threat is simultaneously a creative opportunity. One can even ask if he doesn't play up the threat on purpose, in order to justify the need for a grand re-

48 Nietzsche never himself used the German terms for secularization [Säkularisierung/Säkularisation], which means that I here follow Brusotti's use of the term.

49 These questions are most clearly addressed in Nietzsche's comparison with Pascal in the Nachlass of $D$ (NL 1880, 7[262], KSA 9, 372; cf. Brusotti 1997, 385; Hödl 2009, 419). 
valuation. This revaluation would then be the new dawn, which the title Daybreak [Morgenröte] symbolizes. Needless to say, this reading is not so much an alternative to Brusotti's as a necessary complement. Brusotti draws more on Nietzsche's more pessimistic assessments contained in the notebooks from the period surrounding $D$ than the affirming spirit of the published work. That the spirit of $D$ is one of affirmation does speak volumes about how Nietzsche wanted to present himself. On this point, Brusotti's treatise can in fact be used to support the reading sketched out above. On the basis of Brusotti's investigations and the rather scant evidence provided by Nietzsche's notes, it is near at hand to explain the emphasis on affect in terms of that subtle change in Nietzsche's self-understanding, which led him to re-evaluate his former striving for peace as being a result of a violent passion for knowledge (cf. Brusotti 1997, 168). Far from rejecting this affect, he affirms it and this affirmation grounds his take on affectivity in $D$. So what is clear is that in $D$ at the latest, Nietzsche no longer strives towards a form of life freer from affects in the sense of passion [Leidenschaft] (cf. Brusotti 1997, 642), and instead considers the weakening of affects a positive danger. This does not mean, as I hope to show through textual evidence, that he has become any less suspicious about feelings and especially "high feelings". Nevertheless, Nietzsche's disparaging of striving for emotion for its own sake is a thing of the past and is replaced with a more pronounced, but nevertheless conditional appreciation of the resources present in religion. Though Nietzsche vehemently disagrees with the use to which they are put, Nietzsche values the higher feelings cultivated in religious practice as potential building blocks for a future culture. This future-oriented vision about the value of inherited feelings is far more explicit in $D$ than in $H H$. With this greater appreciation comes the insight that an intellectual critique of religion is not enough to overcome the religious past, at least not if a diminishment of human life is to be avoided. Therefore, the key question of $D$ is, what will replace moral and religious feelings? What will ground a flourishing life instead of moral and religious feelings?

\subsubsection{Reinterpreting and transforming feeling}

On the basis of his interpretation, Brusotti suggests that $D$ can be read as having the goal of transforming feeling (Brusotti 1997, 640-641). While this is a claim that I think requires more textual evidence than provided by Brusotti, especially there is a need to specify how Nietzsche would have mood transformed, it is certainly a solid starting point to recognize that Nietzsche contemplates the possibility of getting rid of certain moral feelings and the possibility of transforming feeling. This focus on feeling is present already in the opening aphorism, in which Nietzsche rhetorically asks whether not the good historian constantly contradicts, in the sense that any history that deals with origins contradicts the feeling that those things we think of as rational can't have an irrational origin (D 1, KSA 3, 19). This short opening aphorism of $D$, which is reminiscent of the opening of $H H$, points out a conflict between the 
historical sense of the free spirit and inherited ways of feeling. The target is the entire domain of morality. For those things "we" think of as rational, the rationality of which things Nietzsche here sets out to question, are of course rules of morality and associated moral feelings. The important explanatory aphorism on the "morality of custom" is exemplary in this regard. There Nietzsche suggests that the advanced moral sense [Gefühl der Sittlichkeit] of his own time derives from the distant past; from fear for the commands of a higher power that must be obeyed without question (D 9, KSA 3, 21-24) In effect, Nietzsche claims that even the morality of his own day is based on a feeling for custom [Gefühl für die Sitte], obeying inherited rules without question, which is destructive insofar as it works against revising moral rules on the basis of experience (D 19, KSA 3, 32). Where is Nietzsche going with all this? Having hinted at the possibility of revising customs and moral rules, how does he seek a way forward?

The big picture, into which Nietzsche's more specific discussions of moral feelings fit, can be gleaned from his words about living in a moral interregnum. The basic idea here is that of a power vacuum, in which it is not clear if there is any commanding morality. In this interregnum, he writes, the old moral feelings and judgements have already lost much of their binding power but new ideals are yet to arise. Therefore, he asks who could tell, what will one day replace moral feelings. There is no explicit answer and the sceptical tone of the aphorism suggests that the answer is no-one. Yet this does not mean that Nietzsche would forsake the task of striving for a specific future. Quite to the contrary, he adds that only the sciences can one day provide the groundwork for new ideals, if not the ideals themselves. Only against this background does Nietzsche's following assertion make sense: that living in the interregnum means that one can live either in a manner oriented toward the past or in an anticipatory, forward-looking mode. That no one can tell what will replace moral feelings, that the future is truly open from the human perspective, means that those who would live for the future are fated to be experiments. In this sense, Nietzsche bids the free spirit to embrace his fate and to desire the experimental life. (Cf. D 453, KSA 3, 274.)

The alliance between scepticism and future-orientation, as in denying that the shape of the future can be known while simultaneously showing the way towards a specific possible future, that the aphorism espouses seems uneasy at best. On a reading emphasizing the sceptical element, one could claim that Nietzsche in fact advances an individualistic morality for free spirits. Indeed, he calls for the free spirits to be their own masters in the interregnum (D 453, KSA 3, 274). Still, his emphasis on the sciences suggests that the experimental life that he envisions is defined by the task to devise ideals that take account of scientific knowledge. Importantly he singles out physiology, medicine and what he calls the sciences of society and loneliness [Gesellschafts- und Einsamkeitslehre]. This latter path of engaging with those sciences that have most to say about human life is the one that Nietzsche himself pursues in $D$ and beyond, on the way to a new dawn; yet this is perhaps nothing more than his 
own path. How does religion relate to this task? Is the religious past only an obstacle, or are there valuable resources in the religious inheritance?

\subsubsection{Religion and the new dawn}

When it comes to religion, $D$ expands on the program of $H H$. Only against the background of $\mathrm{HH}$ can one fully appreciate what Nietzsche means when he speaks of historical refutation as the final refutation of faith in God (D 95, KSA 3, 86-87). The historical method, which as we have seen in the analysis of $H H$ includes psychological analysis, can be used to question the origin of faith in God. According to Nietzsche, this new way is the tune of the day. Such questioning, he claims, renders a rational proof of the non-existence of God unnecessary (D 95, KSA 3, 86). Unfortunately, Nietzsche does not specify exactly why this is the case. This is one of those cases in which the philosopher challenges his reader to fill the missing part and to make up his/her own mind. Against the background of $H H$, it is plausible to see the conclusion as following from a specific understanding of the historical method. The historical method subjects its objects to time, which precludes any possibility of a metaphysics of all that which is timeless, unchanging and immortal. If belief in God requires accepting, as Nietzsche seems to think at least the Christian idea of God does, that the idea of God comes straight from God (as revelation), then showing that the idea of God has a natural origin and has developed gradually is tantamount to a refutation. This argument is supported by Nietzsche's concluding remarks that it was a prejudice of the atheists of former times to believe that a certain kind of rational refutation of theological proofs of God was enough. As the atheists failed to see that new and better arguments for the existence of God could always be devised in the future, they failed to clear the air (D 95, KSA 3, 87). So in a sense the atheists that Nietzsche has in mind were caught up in a game that they could not win; a game wedded to theological method; to methods of reasoning honed in theological schools for centuries. Where they should have attacked the methods of theological reasoning, they were content to refute the results of such reasoning, i.e. the proofs of the existence of god. Contrary to such an approach, Nietzsche trusts the historical method itself to provide the best refutation of theological and metaphysical reasoning (cf. HH I 9, KSA 2, 29-30).

The most important issue which Nietzsche left unclear in $H H$ was what the consequences of such historical and psychological philosophizing look like. What are the emotional consequences and the consequences for values, when the foundations of a dominant religion are eroded? This remains much the same in $D$, as aphorism 453 on the moral interregnum shows (D 453, KSA 3, 274). That the question did preoccupy Nietzsche can be deduced from the fact that the aphorism following the one on historical refutation, the final aphorism of the first book of $D$, deals with the issue. What is remarkable is that it does so in a rather strange way. Nietzsche's speculative comparison of the then current European situation with the Indian situation that led to 
the rise of Buddhism thousands of years ago does little to illuminate the future of Europe. What happens when the old morality is abandoned, "- well, what will come then?” (Hollingdale transl./Clark and Leiter 1997, 55). Although Nietzsche bids the reader to wait and see, he specifies that one has to wait and see that Europe first repeats the steps that India took. This means that after a significant number of people have thrown away belief in God/s and traditional mores, as Nietzsche thinks was the case in India before the rise of Buddhism and as he thinks is the case in the Europe of his day, they should give each other a sign to recognize one another and become a force to be reckoned with. (D 96, KSA 3, 87-88)

On the one hand, one can see the aphorism as a rather futile attempt by Nietzsche to comprehend the situation facing himself and his time through analogy. Read that way, it raises questions about Nietzsche's historical sense. For who could say in advance what the future will look like? (cf. D 453, KSA 3, 274). On the other hand, one can see the analogy as an excuse for presenting the demand that those who no longer believe in inherited notions such as "God" should become aware of their historical situation and conscious of themselves as a force to be reckoned with. This is nothing less than a vision of an international community of free spirits, if not an atheistic religion. Nietzsche's decision not to refrain from presenting a vision of the future development of European culture can thus be read in terms of an attempt to actively influence the shape of the future. So here again, Nietzsche is concerned with the new dawn to come and again he does not say anything specific about this coming time. There is not much to be found on the topic in the passages that directly deal with religion, but there are passages that reveal how the new vision relates to that religiously sanctioned morality which it supersedes. If one were to single out one passage, that above others helps to clarify Nietzsche's position, it would be aphorism 103.

In aphorism 103, Nietzsche clarifies in what sense he denies morality. He explicitly distances his view from a universal scepticism concerning moral motivations. So it is not always the case that a person explaining his actions in moral terms is deceiving himself and others as to the true motivations of his actions. ${ }^{50}$ This idea conforms to the interpretation I developed in chapter three that Nietzsche thinks it is admissible to refer to conscious mental states as influencing action and doesn't view all action through a rigid drive theory. Because deception is still always a possibility, (after all one cannot access the phenomenal world of another person), Nietzsche (invoking the spirit of La Rochefoucauld) does go on to suggest that that a certain doubt regarding the stated motivations of people is only healthy. His own position, however, is

50 Clark and Leiter here read Nietzsche as rejecting the view he advanced in $H H$ that all actions are egoistic (Clark and Leiter 1997, xxiv-xxv). I think there is more reason to speak of clarification than rejection, as Nietzsche nowhere in $\mathrm{HH}$ makes a systematical case for the kind of psychological egoism that Clark and Leiter presuppose. The perspective that he strives for is rather one that makes the distinction between selfishness and selflessness redundant. For a similar critique, see Franco 2011, $26-29$. 
rather to question that moral actions would be based on any moral truth about the world. According to Nietzsche there is no reason to question that people have moral feelings, and act according to them. He specifically mentions that countless people feel immoral, but criticizes them for thinking of their emotional state as expressing a truth about themselves and about the world. A good example would be the jump from feeling immoral to believing that one is immoral and depraved and that this is the way the world is because of original sin. He also makes clear that critiquing morality in this way does not mean to turn everything on its head. Many actions deemed moral should be encouraged, but for other reasons than strictly moral ones. This requires learning anew in order to feel anew: "We have to learn to think differently - in order at last, perhaps very late on, to attain even more: to feel differently." (Hollingdale transl./Clark and Leiter 1997, 60; D 103, KSA 3, 91-92)51

The aphorism shows beyond any doubt that one goal of the critique of morality in $D$ is to make it possible to feel differently about matters usually thought of as moral. Since morality shapes so much of experience, this goal amounts to nothing less than feeling differently about existence more generally. Is feeling differently then the ultimate goal of Nietzsche's criticism, the most important goal among many goals, or perhaps just one goal among equally important goals? Because Nietzsche's explicit statements on the topic are so cursory in $D$, it is on their basis next to impossible to ascertain whether Nietzsche here even considers feeling differently as a goal in its own right, or whether it is rather a sign of something else, e.g. that one has internalized the idea that there are no moral truths. On the grounds that Nietzsche already in the period surrounding the publication of $H H$ understands his philosophy as the pursuit of a mountain air ideal, and because his later thought culminates in thinking what he deems the highest possible affirmation, an affective stance toward the earth informed by the thought of Eternal Recurrence, it is justified to assume provisionally that enabling the transformation of feeling was the most important goal of $D$. Before looking more closely at the evidence concerning authorial intention, and what can be gained from an interpretation of Nietzsche's use of mood, there is one final issue that has to be sorted out. Any further discussion about Nietzsche's project of transforming feeling presupposes that Nietzsche does not simply reject the value of high feelings and strive for a general cooling down of affect.

In the discussion on $H H$, it was established that Nietzsche thinks that above all those accomplishments, experiences and states of mind that are granted the highest value are associated with a higher world. In short, all higher feelings are given a supernatural origin. In $\mathrm{HH}$, this knowledge led to a sceptical stance towards all extraordinary feelings, especially those associated with religion. The free spirit nevertheless acknowledges the value of such feelings for contemplation, and perhaps even

51 “umzulernen - um endlich, vielleicht sehr spät, noch mehr zu erreichen: umzufühlen” (D 103, KSA 3, 92). 
sees a role for them in the future. In $D$, Nietzsche repeats the same basic criticism, ${ }^{52}$ concluding that: "wherever a man's feelings are exalted, that imaginary world is involved in some way" (Hollingdale transl./Clark and Leiter 1997, 24-25; D 33, KSA 3, 42). Furthermore, he writes:

It is a sad fact, but for the moment the man of science has to be suspicious of all higher feelings, so greatly are they nourished by delusion and nonsense. It is not that they are thus in themselves, or must always remain thus: but of all the gradual purifications awaiting mankind, the purification of the higher feelings will certainly be one of the most gradual. (Hollingdale transl./Clark and Leiter 1997, 25; D 33, KSA 3, 42-43)

While this passage, which echoes $H H$, clarifies that the attack on metaphysical interpretations is not intended to be an attack on exalted states of mind, it simultaneously points out that such feelings are through historical associations so entwined with religion and metaphysics that they must for the time being be viewed with suspicion. The aphorism proves that Nietzsche is just as suspicious of high feelings in $D$ as in $\mathrm{HH}$, and yet it also shows that he is even more aware of their value. That the free spirit does not deny the value of high feelings is apparent from the regret that he expresses at the necessity of viewing such emotional states with suspicion. Nevertheless, this regret does not speak of nostalgia nor does it imply that the free spirit seeks to rid himself of such feelings; it is rather meant to point out that the purification of feeling is a task that has only become more pressing. In contrast to $\mathrm{HH}$, where purification is associated with calm contemplation which turns feelings into objects of knowledge, purification in $D$ is best understood as an active and creative process of transformation. This interpretation finds support in the oft-cited aphorism 210:

\begin{abstract}
210. The thing itself. - Formerly we asked: what is the laughable? as though there were things external to us to which the laughable adhered as a quality, and we exhausted ourselves in suggestions (one theologian even opined that it was 'the naivety of sin'.) Now we ask: what is laughter? How does laughter originate? We have thought the matter over and finally decided that there is nothing good, nothing beautiful, nothing sublime, nothing evil in itself, but that there are states of soul in which we impose such words upon things external to and within us. We have again taken back the predicates of things, or at least remembered that it was we who lent them to them: - let us take care that this insight does not deprive us of the capacity to lend, and that we have not become at the same time richer and greedier. (Hollingdale transl./ Clark and Leiter 1997, 133; D 210, KSA 3, 189)
\end{abstract}

First of all, there is an interesting parallel here to the aphorism on the historical refutation of faith in God. Today it is asked how laughter arises and one enquires into its origin. In this case, however, applying the historical method does not result in a ref-

52 "So verachtet der Mensch im Banne der Sittlichkeit der Sitte erstens die Ursachen, zweitens die Folgen, drittens die Wirklichkeit, und spinnt alle seine höheren Empfindungen (der Ehrfurcht, der Erhabenheit, des Stolzes, der Dankbarkeit, der Liebe) an eine eingebildete Welt an: die sogenannte höhere Welt." (D 33, KSA 3, 42) 
utation of laughter. To the contrary, the aphorism emphasizes the value of the ability to have states [Zustände], from which to value things. Losing the affective capacity to value would indeed be a diminishment. So instead of removing emotion or turning emotions only into objects of knowledge, the affects have to be transformed. To what extent this is a matter of redirecting emotions is an interesting question, especially when it comes to religious feelings. The affective configuration that supports belief in God is something that has developed historically through religious practice over a long time span. Does Nietzsche call free spirits to redirect those feelings that have been directed at the idea of God? Such an endeavour sounds Feuerbachian, in the sense of taking back the predicates of God and redirecting them at humanity (cf. Feuerbach 1849). ${ }^{53}$ While the analogy can initially help to grasp what Nietzsche is after, it is not adequate to describe what Nietzsche is doing. Already in $\mathrm{HH}$, Nietzsche was extremely critical of efforts to transfer religious feelings to such domains as art and politics. Instead of simply redirecting religious feelings for God, Nietzsche would see such feelings transformed at the root. In $D$, such radical transformation goes by the name of purification. Hödl (2009, 311 and 426) and Brusotti (1997, 408-409 and 423) have drawn similar conclusions, though they correctly note that Nietzsche's vocabulary at times comes deceptively close to suggesting the adoption of a Feuerbachian perspective.

Now that it has been established that Nietzsche does not reject the value of high feelings, and instead calls for a purification of exalted states, it is possible to turn to the question, what role mood plays in the philosophical project of Daybreak.

\subsection{Nietzsche's use of mood in D}

The very same questions that were asked about $H H$ are worth asking about $D$. Does Nietzsche make use of mood in his writing in $D$ ? And if yes, how and to what end? How does this use of mood relate to the philosophical project of $D$ ? Is understanding the mood or moods that are expressed in $D$ essential to understanding its philosophical contents?

As was the case with $H H$, the most instructive evidence can be found in Nietzsche's letters. A key difference between $H H$ and $D$ is that in the case of the latter work there is far more evidence that directly bears on the question of authorial intention that precedes the publication of the book. The most interesting discussion in this regard is the one that Nietzsche was having with Köselitz in February 1881. This dis-

53 Nietzsche became acquainted with Feuerbach's work The Essence of Christianity [Das Wesen des Christentums], or at least the most important of its arguments, during his school-years in Schulpforta, which can be seen in texts by the 17-year old student, as Hödl points out (Hödl 2009, 214-215; cf. Young 2010, 36). Insofar as one can speak of lasting influence, it has to do with Nietzsche's adoption and development of Feuerbach's idea that all conceptions of God are human creations, projections of desires of the heart (cf. Hödl 2009, 221). 
cussion was above all concerned with the choice of title. In a postcard sent to Köselitz on 22 February 1881, Nietzsche explains why he has chosen to change the title of the work (KGB III/1, Bf. 83). Despite what he takes to be the less good taste of the title "Eine Morgenröte", its too enthusiastic, too oriental connotations, he favours it because he thinks it leads the reader to expect a more joyful mood in the book. With the title "Eine Morgenröte", he suggests, one sets out to read the work in a different mood than if the title would not raise the expectation of a new dawn. He even goes as far as to suggest that without the promise of a glorious dawn the book would come across as too bleak. ${ }^{54}$ Whether Nietzsche here refers only to the title or also to the numerous aphorisms suggesting that a new dawn is near cannot be said with any certainty; let it nevertheless be said that there are good grounds to pay attention to the matter: Indeed, I will argue that raising expectations is perhaps the single most powerful trick that Nietzsche uses to enable a redirection of mood in $D$. For now it is enough to note that these considerations of mood that spoke in favour of the title outweighed all the downsides, and only for this reason do we know the work with the title Daybreak. Already on account of this letter alone, one is tempted to conclude that Nietzsche, by the time of $D$, was not only fully aware of the power of mood but that he also put this knowledge into practice. The discussion with Köselitz continues after the publication, and further strengthens that conclusion.

Writing to Köselitz about $D$, Nietzsche exhorts his friend to read it as a whole and to try to make a whole out of it, as an expression of a passionate state. ${ }^{55}$ What can be made out of the fact that Nietzsche wanted his friend to read his newly published work as expressing a passionate state? Whether this fact can be generalized, and turned into the form that $D$ expresses mood and Nietzsche meant it to do so, is a more difficult question. There is of course the problem, which Brusotti has drawn attention to, that Nietzsche seems to contradict himself (Brusotti 1997, 22). Indeed, only about two months after the letter quoted above Nietzsche complains to Köselitz about being an aphoristic human [Aphorismus-Mensch], bound to write in a fragmentary mode that only suggests that the text makes up a whole, or even worse: that the text only suggests the need for a whole (KGB III/1, Bf. 143). In addition to this letter, there is also the digression inserted into the book itself, which states:

Digression. - A book such as this is not for reading straight through or reading aloud but for dipping into, especially when out walking or on a journey; you must be able to stick your

54 'Titel! Der zweite 'E<ine> Morgenr<öthe>' ist um einen Grad zu schwärmerisch, orientalisch und weniger guten Geschmacks: aber das wird durch den Vortheil aufgewogen, daß man eine freudigere Stimmung im Buche voraussetzt als beim andern Titel, man liest in anderem Zustande; es kommt dem Buche zu statten, welches, ohne das Bischen Aussicht auf den Morgen, doch gar zu düster wäre! - Anmaaßend klingt der andre Titel auch, ach, was liegt noch daran! Ein wenig Anmaaßung mehr oder weniger bei solch einem Buche!” (KGB III/1, Bf. 83)

55 "lesen Sie es als Ganzes und versuchen Sie ein Ganzes für sich daraus zu machen - nämlich einen leidenschaftlichen Zustand” (KGB III/1, Bf. 119). 
head into it and out of it again and again and discover nothing familiar around you. (Hollingdale transl./Clark and Leiter 1997, 191; D 454, KSA 3, 274)

Nietzsche seems to contradict himself. Nevertheless, Brusotti argues that Nietzsche meant the work to form a whole. According to Brusotti, each passage of $D$ is meant to express the passionate state that Nietzsche wanted his friend Köselitz to grasp. In this view, it is the task of the reader to realize the entirety of the passionate state behind each and every aphorism. On account of letter 119 (to Köselitz) and despite the aphoristic form, Brusotti thus concludes (on behalf of Nietzsche!) that only through the passion of knowledge is the work made a whole. ${ }^{56}$ While the evidence of Nietzsche's letters is compelling, Brusotti does not back up his thesis with enough textual evidence from within $D$. From Brusotti's treatment of the issue it is still unclear exactly what role mood plays in $D$ and what its philosophical status is. I will delve deeper into these issues through engaging the work of Rebecca Bamford, who has written in more detail on Nietzsche's use of mood in $D$ (Bamford 2014).

\subsubsection{Rebecca Bamford's thesis about Nietzsche's use of mood}

Apparently unaware of Golomb's very similar efforts regarding $H H$, Rebecca Bamford seeks to tease out an understanding of the way Nietzsche uses mood in $D$ from the aphorisms that make up the work. ${ }^{57}$ In her paper "Mood and Aphorism in Nietzsche's Campaign Against Morality" she advances the thesis that "Nietzsche uses mood (Stimmung) to identify, and counter, the highly problematic and deeply entrenched authority of the morality of custom" (Bamford 2014, 56). Unlike Golomb, Bamford explicitly presents her thesis as a contribution to answering the question why Nietzsche uses the aphoristic form (Bamford 2014, 55). Consequently, she not only pays attention to the content of the aphorisms but thematizes "performative" aspects of Nietzsche's writing as well. That does not mean that her work would be any less problematic; to the contrary. Nevertheless, it is definitely worth interrogating.

Bamford is right to stress the affective dimension of $D$. As our brief discussion has shown, there is ample evidence that Nietzsche considers feelings of utmost importance to those problems of morality that concern him. Bamford's recognition of the philosophical importance that Nietzsche attaches to feelings is a welcome corrective to the overtly cognitive perspective on $D$ taken by Clark and Leiter in their influ-

56 "Nur durch die Leidenschaft der Erkenntnis ist Morgenröthe ein Ganzes: durch die Leidenschaft des Autors und durch die des Lesers." (Brusotti 1997, 22)

57 This is not the only similarity between the two. Bamford's remarks on Nietzsche's use of mood in $D$ are best understood against the background of her reading of the work as a therapeutic narrative (Bamford 2015). Likewise, Golomb's thesis about Nietzsche's use of mood in $H H$ is part of his larger argument about the therapeutic intentions of Nietzsche's philosophy (cf. Golomb 1989). 
ential introduction that has defined the Anglophone reception of the book. ${ }^{58}$ It is however precisely there where Bamford goes beyond a mere recognition of the importance of affects in Nietzsche's thinking towards a positive thesis about Nietzsche's use of mood that the evidence that she presents has to be examined carefully. There is good reason to begin by emphasizing a specific problem that Bamford downplays. If one looks at Nietzsche's statements on mood [Stimmung] in $D$ one can detect an ambivalence in his thinking on the use of mood; an uneasiness about the role of affectivity in thought. This ambivalence is present in aphorism 28 (D 28, KSA 3, 38), which Bamford grants a key role in her argument and which should be given careful consideration in any interpretation of Nietzsche's thinking on mood (cf. Bamford 2014, 66-67). For the sake of clarity, here is the entire aphorism:

28. Mood as argument. - 'What is the cause of a cheerful resolution for action?' - mankind has been much exercised by this question. The oldest and still the most common answer is: 'God is the cause; it is his way of telling us he approves of our intention.' When in former times one consulted the oracle over something one proposed to do, what one wanted from it was this feeling of cheerful resolution; and anyone who stood in doubt before several possible courses of action advised himself thus: 'I shall do that which engenders this feeling.' One thus decided, not for the most reasonable course, but for that course the image of which inspired the soul with hope and courage. The good mood was placed on the scales as an argument and outweighed rationality: it did so because it was interpreted superstitiously as the effect of a god who promises success and who in this manner gives expression to his reason as the highest rationality. Now consider the consequences of such a prejudice when clever and power-hungry men availed themselves - and continue to avail themselves - of it! 'Create a mood!' - one will then require no reasons and conquer all objections! (Hollingdale transl./Clark and Leiter 1997, 22; D 28, KSA 3, 38)

The least that must be said on the basis of the aphorism is that Nietzsche is aware of the possibility of using mood as a tool of manipulation; he is in other words aware of the power of mood. To conclude on the basis of the aphorism, that he himself would endorse this kind of use of mood is dubious, if not out of the question. It can reasonably be assumed, granted that one takes his emphasis on intellectual integrity [Redlichkeit $]^{59}$ at face value, that he would reject the use of mood in place of argument in a philosophical context. I read Bamford as not necessarily falling into this trap when she suggests that the aphorism leaves open the possibility of a positive use of mood (Bamford 2014, 67). Indeed, there is no reason to assume that there is an unresolvable contradiction between this aphorism and any possible positive use of mood by Nietzsche. What bothers Nietzsche most about the use of mood that he criticizes

58 The deficiencies of the perspective adopted by Clark and Leiter will be shown in the following discussion on the specific case of superstitious fear.

59 See the similar aphorism 543. Do not make passion an argument for the truth [Nicht die Leidenschaft zum Argument der Wahrheit machen] (Hollingdale transl./Clark and Leiter 1997, 216-217; D 543, KSA 3, 313-314). See also Brusotti on the concepts Redlichkeit and Leidenschaft der Redlichkeit (Brusotti 1997). 
is that it rests on and supports metaphysical, "superstitious" interpretations of mood. The key question is to what use mood is put: Perhaps mood can play another role in philosophy than that of simply overriding arguments? Perhaps mood can be used to provide an affective background sense against which an argument or series of arguments can better be understood? Perhaps using mood is the only way to work against an established mood that hinders free thinking about any number of issues? Or perhaps mood can simply be used to compliment arguments and give them life? Such questions might have crossed Nietzsche's mind, but it is best to refrain from any claims of the sort unless there is reasonably acceptable evidence to support them. How exactly Nietzsche put his thinking on mood into practice has to be proven. The next logical step is to look for passages in which Nietzsche in fact does make use of mood. Before we examine the evidence for any positive use of mood by Nietzsche, we must digress to consider the presuppositions that Bamford's thesis rests on.

\subsubsection{The presuppositions of Bamford's thesis}

Bamford assumes that Nietzsche is using mood to counter another mood; the "mood of fear" (Bamford 2014, 61). According to Bamford, he takes it that the mood of fear supports morality by preventing new feelings from developing. Why would this be the case? I will here expand on Bamford's cursory remarks, since this issue is foundational for her case. In this reading of Nietzsche, fear plays a decisive role in morality, as it is really fear that lies at the root of the prohibition to revise morals. So fear begets unconditional obedience to custom, and obedience to custom prevents even harmful customs from being corrected (cf. D 19, KSA 3, 32). This fear is deeply rooted and therefore best understood as a mood, which means that it cannot be fought against only through reason but also requires a reorientation of affect (cf. Bamford 2014, 74). Against this background, the idea of using mood against the mood of fear is understandable. Such a use of mood against mood would not contradict Nietzsche's distaste against the way the power-hungry use mood as a tool of manipulation, because it is a case in which mere rational arguments are not enough to defeat a harmful and false understanding of morality. This idea, that Nietzsche seeks to use mood against mood, is the starting point for Bamford's discussion of Nietzsche's use of mood in $D$. The sceptical reader might however ask: does such talk about a mood of fear make sense in the first place?

Bamford's talk of a "mood of fear" is not as problematic as it at first sounds, and it is certainly no reason to dismiss her argument. That most philosophers (other than Heideggerians ${ }^{60}$ do not consider fear a mood is irrelevant, as Nietzsche himself does

60 Heidegger infamously treats fear as a mood [Stimmung] in Sein und Zeit (cf. Heidegger 2006, 140). Quite a few phenomenologically inclined philosophers have followed in his footsteps, e.g. Lars 
not make any clear cut distinctions between affects, moods, and states. He does indeed repeatedly suggest, as Bamford rightly points out, that superstitious fear is one of the pillars sustaining customary morality (cf. D 9, KSA 3, 22; D 23, KSA 3, 34; D 104, KSA 3, 92). From Nietzsche's discussion it is clear that this fear is ever-present in cultures that rely on customary morality. Clark and Leiter also recognize that superstitious fear supports the morality of custom, but write about it as a matter of superstitious beliefs to be rid of through rational arguments (Clark and Leiter 1997, xxxiii and xxxiv). This failure to acknowledge that Nietzsche clearly does not think rational arguments to be enough is understandable given the misleading translation of $D 103$ that Clark and Leiter use to support their interpretation (cf. Clark and Leiter 1997, xxxiii). The translation imputes that "We have to learn to think differently - in order at least, perhaps very late on, to achieve even more: to feel differently", which implies that thinking differently is enough to feel differently in the future. The original German edition speaks about the necessity to learn anew [umzulernen], which can be understood in a much broader sense than merely thinking differently. In particular, there is reason to believe that Nietzsche thought the process of learning anew to be affective through and through and as much a matter of practice as of critical cognition. In any case, the evidence that Nietzsche believed that merely thinking differently is not enough is overwhelming, which would seem to support Bamford's starting point. In the following, I will examine a particular case, which supports Bamford's reading against Clark and Leiter but also complicates the picture that the mood of fear would be the only affective constraint that prevents a dawn of transformed feelings.

According to Nietzsche, fear is not the only feeling preventing new post-moral interpretations of feelings from developing. The aphorism The brake (D 32, KSA 3, 41) makes the case that pride also serves this function. In fact, Nietzsche quite a few times indicates that as the archaic sense for the sanctity of all custom has been weakened (D 9, KSA 3, 21-24), the role played by fear has also been diminished even if moral fear is still active in and around us and not entirely a thing of the past (cf. D 5, KSA 3, 20; D 10, KSA 3, 24; D 18, KSA 3, 30 -32; D 551, KSA 3, 551). Most certainly, Nietzsche assumes that the free spirits he describes no longer think of themselves as bound by conventional morality. Why would people, including some who think of themselves as free spirits, then in Nietzsche's own time still act in accordance with moral conventions, even when it harms themselves and perhaps even when they no longer think that it is rational to do so? Nietzsche's answer in aphorism 32 is that these people would rather suffer because of their morality than be rid of their self-imposed suffering, because this suffering provides the sublime feeling of being in contact with a truer world, a higher or deeper reality. He sees pride at work

Svendsen whom Bamford mentions to justify her approach (Bamford 2014, 61). Of course, a sole reference to one contemporary philosopher is not much of a justification. In this case, however, I think one need not look beyond Nietzsche's own thinking for a sufficient justification. 
in this choice, pride resisting a younger yet more truthful understanding of morality. The implication is clear: That there is a new understanding of morality that has at least for some people already replaced older understandings of morality (presumably based on obedience and fear) does not matter much if it remains a matter of the head and not also a matter of the heart. Nietzsche ends the aphorism by asking what power one should use to set aside this constraining pride; this brake. "More pride? A new pride?", he asks, clearly aware that an intellectual attack against such pride is not going to be enough. (Hollingdale transl./Clark and Leiter 1997, 24; D 32, KSA 3, 41)

Unsurprisingly, Clark and Leiter overlook this important aphorism in their discussion on what it takes to get rid of superstitious beliefs (Clark and Leiter 1997). More alarmingly, Bamford also ignores the aphorism. In the light of this aphorism, Bamford's starting point seems incomplete and her thesis consequently has to be adjusted. If Nietzsche indeed uses mood to counter the morality of custom, the mood in question would have to be one that not only counters (superstitious) fear, but also works against the kind of pride described in aphorism 32. Alternatively, there would have to be at least two different moods at work, a first one that allows one to move beyond fear and another that enables one to set aside a perverse pride in one's suffering for morality. This second alternative does not present any serious problems as long as the moods in question are not thought of as entirely opposed (cf. HH I 14, KSA 2, 35) because that would threaten the unity of the work, which Nietzsche himself wanted his friend Köselitz to read as expressing one passionate state of mind [einen leidenschaftlichen Zustand] (KGB III/1, Bf. 119). Now that the presuppositions of Bamford's thesis have been examined, it still remains to be seen what evidence can be found that Nietzsche in fact makes use of mood in $D$ to further his ends.

\subsubsection{Interruptions and expectations? Nietzsche's techniques of communicating mood in $D$}

Bamford claims that in $D$ 146, besides arguing against the morality of custom, "Nietzsche shows how mood can be used performatively to campaign against morality" (Bamford 2014, 68). This claim rests on Nietzsche's self-interruption at the very end of the aphorism; his exclamation "but now not a word more! A glance is enough; you have understood me” (Hollingdale transl./Clark and Leiter 1997, 92; D 146, KSA 3, 138). According to Bamford, Nietzsche interrupts himself after having criticized moralistic understandings of compassion just as he is about to present an alternative moral vision. In this view then, Nietzsche interrupts himself when he is about to "adopt problematic moral talk" and this interruption "performs" resistance to the authority of morality (Bamford 2014, 68). Bamford is certainly right that something important about Nietzsche's use of mood can be learned from aphorism 146, and self-interruption does play an important role in some other important aphorisms 
of $D$, not least in aphorism 96 (D 96, KSA 3, 87-88). However, a closer look at both of these aphorisms reveals that Bamford's interpretation is problematic; in other words, I will argue that Bamford is right about aphorism 146 being a good example of Nietzsche's use of mood for the wrong reasons.

The main problem in both cases is that Nietzsche actually gives a glimpse of his alternative vision before interrupting himself, and there is no reason to read his interruptions as repudiations. In aphorism 146 he triumphantly asks whether his desire to move beyond a simplistic understanding of pity [Mitleid] towards a vision in which great sacrifices that serve the future good of humanity are sanctioned is not itself already the expression of a higher and freer mood [Stimmung] (D 146, KSA 3, 138). In aphorism 96, as we have seen, he even goes on to give specific instructions based on his vision of the future (i.e. that nonbelievers should give each other a sign) (D 96, KSA 3, 88). Strategic interruptions and sceptical cautions need not indicate anything else than that the time is not yet ripe to give definite answers, as the aphorism on living in a moral interregnum suggests (D 453, KSA 3, 274). In general, Nietzsche is not as adverse to "moral talk" in $D$ as Bamford suggests, at least not to all kinds of speaking about morality. Vehemently objecting to a morality based on obedience and metaphysical ideas in no ways rules out talk about desirable conditions, virtues and actions. ${ }^{61}$ Indeed, an even more daring thesis about Nietzsche's use of mood can be advanced on the basis of the aphorisms in question. What unites all these three aphorisms is that Nietzsche plays with the expectations of the reader; and by raising expectations shapes the mood of the reader. In this perspective, Nietzsche's navigation between scepticism regarding that which is to come and the affirmation of a specific vision of the future can be viewed as a strategic technique to communicate a mood of joy without giving up scepticism. Bamford does not even consider this alternative explanation for Nietzsche's self-interruption at the end of aphorism 146. Instead, she quickly moves forward and simply notes that "performative claims" that serve the same end she thinks the self-interruption serves are found in numerous aphorisms of $D$.

To further strengthen my interpretation, I will compare aphorism 96 with two equally important aphorisms that exemplify Nietzsche's "use of mood". The final aphorisms of books one, two and five, "In hoc signo Vinces" (D 96, KSA 3, 87-88), Distant prospect (D 148, KSA 3, 139-140) and We aeronauts of the spirit (D 575, KSA 3, 331), all exhibit the same pattern. All of these aphorisms present visions of a future to desire, a future to strive for. Aphorism 96 holds out the possibility of European free spirits becoming conscious of their collective power. Aphorism 148 ends by suggesting that the revaluation of egoistic action will lend a perspective that purifies the world of evil by abolishing the moral idea of evil. Aphorism 575, which closes the entire book, finally presents the free spirit with a vision of more mighty spirits who

61 After all, Nietzsche doesn't shy away from assembling a list of his very own personal cardinal virtues (see D 556, KSA 3, 325). 
will strive in the same direction and reach ever further. By presenting such visions, Nietzsche is countering the idea that moving beyond conventional morality would inevitably lead an individual or a community to a bleak wasteland. Of course, no one can say with certainty that it does not. After all, Nietzsche presents the move beyond conventional morality as an experiment! What matters is that the experiment cannot even begin as long as one is convinced that the end result is catastrophic. Where do the birds that cherish the free air and open seas fly? What is their destination? Perhaps that matters little as long as they're driven by their desire, worth more than any other desire, ${ }^{62}$ this joy of striving ever higher in clear air. Any ultimate "what for?" is replaced with a provisional answer: for the views, for the joy. By providing glimpses of a glorious dawn, through this mood of joy, Nietzsche arguably seeks to inculcate the same desire in the reader.

\subsubsection{Aphorisms for manipulation?}

When Bamford continues her discussion on Nietzsche's use of mood, she comes close to the viewpoint that communicating joy is an important ingredient in this endeavour. Instead of speaking about Nietzsche's play with expectations she introduces the idea that the tone of Nietzsche's discussions about ideal moods and affective states is itself a powerful transformation tool (Bamford 2014, 70). Bamford's elaborations are worth interrogating closely. If, in general, one can agree with Nietzsche's assessment in $E H$ that $D$ is a book of affirmation (EC, KSA 6, 329-330), it is all the more true that the tone of those aphorisms in which Nietzsche touches upon future feelings is especially elated. Unfortunately, Bamford goes unnecessarily far in her interpretation when she theorizes $D$ as an "environmental structure" that has been "constructed to manipulate and transform our mental processes" (Bamford 2014, 70). What at first sight might seem only a strong statement of the thesis advanced here, turns out to be nothing less than an explanation for Nietzsche's choice of the aphoristic form. In this view, "the aphorism, in writing, becomes a feature of the environment and as such, is able to facilitate the campaign to counter the prevailing mood of superstitious fear" (Bamford 2014, 70).

The thesis is either banal in the sense that any piece of writing, whether in aphoristic form or not, becomes a part of the environment and can in principle serve the function that Bamford attributes to $D$, or then the thesis is extremely ambitious if it is understood as a claim that Nietzsche chose the aphoristic form of $D$ because it is particularly suited to serve as external support for his campaign against morality. The first interpretation of the thesis is of no interest and the second one is highly problematic. Bamford fails to provide any solid reason why the aphoristic form should be particularly suited to this task; nor does she provide any evidence

62 “dieses mächtige Gelüste, das uns mehr gilt als irgendeine Lust” (D 575, KSA 3, 331). 
concerning Nietzsche's intentions that would support her thesis. In advancing her reading, Bamford merely refers to contemporary thinking in philosophical psychology, specifically the externalist theory of cognition of Mark Rowlands, according to which some mental processes depend on external support (cf. Bamford 2014, 70). As an externalized testament of the campaign against morality, to which one can return again and again, the physical book can be used as therapy whenever one would stray from the goals one has set against morality (Bamford 2014, 70). Additionally, the idea would seem to be that the aphoristic form is able to serve the attack on morality better than any other because it is more open-ended and engages the reader to take in what he can and fill in what he deems missing; thus countering the a kind of moral instruction that has to be obeyed. Instead of giving definite answers, the aphoristic form would convey a mood that allows one to break free from the shackles of the morality of custom.

While this approach can help illuminate the effect that $D$ has for some readers of the book, perhaps even the effect that Nietzsche thought it should have, ${ }^{63}$ I think the introduction of a theoretical perspective from contemporary philosophical psychology only obscures the difficult and ultimately unanswerable question about what led Nietzsche to adopt the aphoristic form and in no way illuminates Nietzsche's use of mood in $D$. In this regard, it is nevertheless interesting to compare Nietzsche's 1877 plan for a travel book [Reisebuch] with his description of Daybreak in the Digression [Zwischenrede] (D 454, KSA 3, 274). In his 1877 plan, he envisions a book purposely composed for readers who lack the time and attention required to wade through a systematic treatise from beginning to end. Such a book would not be read through but opened and closed repeatedly and at each opening the reader would take in a thought or two for reflection. Nietzsche even suggests that such a book would encourage free reflection, in contrast to the forced reflection involved in following a longwinded systematic argument. Despite the unsystematic character of the book, the free reflection that it promotes would result in a general realignment of views [Umstimmung der Ansichten]. (Cf. NL 1876-77, 23[196], KSA 8, 473-474.) It is not at all implausible that $D$ serves a similar function, though there is no unambiguous evidence to suggest that Nietzsche thought so. In any case, Nietzsche's words about enabling free reflection can hardly be reconciled with Bamford's talk of "manipulation”. With this in mind, we can return one final time to the discussion on ideal moods in $D$ and the expectations that Nietzsche raises.

63 In $\mathrm{EH}$ he presents the book as producing a "scheuen Vorsicht vor Allem, was bisher unter dem Namen der Moral zu Ehren und selbst zu Anbetung gekommen ist" and emphasizes that this negative effect is in no way contradicted by the affirmative tone of the work (KSA 6, 329). 


\subsubsection{Ideal moods in $D$}

In aphorism 551, Of future virtues, Nietzsche asks: where are the astronomers of ideals, where are the poets of that which could be? Where are those who would give a foretaste of that which is to come, not to speak of those possibilities that will never be reality on earth? (D 551, KSA 3, 321-322) If the poets do not speak of such ideals, Nietzsche surely does. Thus far, we have seen that Nietzsche's ideal mood is intimately associated with a scepticism that is indissociable from joy (in incessant striving and expectation). For Nietzsche personally, this meant above all creative striving. Aphorisms 473 of book five is especially instructive in this regard:

473. Where one should build one's house. - If you feel yourself great and fruitful in solitude, a life in society will diminish you and make you empty: and vice versa. Powerful gentleness, like that of a father: - where you are seized by this mood, there found your house, whether it be in the midst of the crowd or in a silent retreat. Ubi pater sum, ibi patria. (Hollingdale transl./Clark and Leiter 1997, 196; D 473, KSA 3, 283)

That Nietzsche bids the reader to build his house where this mild mood of power sets in is perhaps best understood against the background of his own experience of being on the move. This point was already made by Stefan Zweig (Zweig 1925, 291), who emphasized the South as that which allowed Nietzsche to de-Germanize himself. Indeed, the aphorism lends itself to be read as a cosmopolitan rejection of provincialism/nationalism based on birth and the affirmation of a different kind of fatherland, but there is even more to it than that. What is most striking here is that Nietzsche in effect asks one to find one's home in a mood, not only through a mood. "Ubi pater sum, ibi patria", can freely be translated as "where you are creative, there is your homeland", due to the emphasis placed on where one feels fruitful and on the metaphor of paternity. That feeling Nietzsche had found to be strongest in himself in the Engadine, ${ }^{64}$ but it was by no means bound to any specific location. Indeed, much could be said in favour of the case that Nietzsche thought he was carried on by the air, with which he felt to be related, wherever he went. Be that as it may, what matters most to us here is that Nietzsche unambiguously advices the reader to follow his own way, but that this advice is based on thinking of a specific mood as greater than others. Promoting this kind of individualism does not contradict promoting a specific mood. In this regard, this aphorism can be used to argue against what I take to be a major misunderstanding about Nietzsche's philosophical project that re-

64 Young writes beautifully about how Nietzsche upon his arrival in the Engadine in 1879 "immediately felt in tune with the valley which, from now until his final collapse, would be the nearest he would ever come to a homeland" (Young 2010, 277). It is of course the case that Nietzsche did not return to the Engadine for two years after his first visit, but this does not diminish the truth of Young's statement, as Nietzsche was himself very clear about the matter. Not only did he record his initial experience of this feeling in strong words (HH II, WS 338, KSA 2, 699), he also incorporated the landscape of the Engadine into his philosophy through metaphors drawn from this unique valley. 
surfaces again and again in scholarship. It is not the case that Nietzsche would abandon all claims to instruct and instead promote a full-blown individualism, nor is it the case that Nietzsche would have the reader accept his own revaluation of specific moral customs as binding. These are not real options; the choice need not be thought of as one between an individualistic and a communitarian Nietzsche. Although Nietzsche wants his readers to go their own way, he would arguably have them do this in order to dwell in that mood which most heightens their feeling of power, which he understands to be at least related to the mood which he himself feels to be the highest. With this in mind, we can begin to approach Nietzsche's Gay Science.

\subsubsection{Conclusion}

Nietzsche can be said to "use" mood in $D$ to activate a desire to live the experimental life of the free spirit beyond conventional morality. He considers this affective reorientation necessary, because a rational attack on the religious and metaphysical forces sustaining customary morality is not enough to open the way towards a new dawn. Both negative feelings such as fear and positive, sublime feelings of being in touch with a higher world stand in the way. In order to overcome these affective obstacles, Nietzsche invites the reader to join his project not only through rational persuasion but also by playing with expectations, by providing glimpses of a sublime dawn. This technique is supported by the joyful tone of the work. By invoking future possibilities, he still does more than just communicate a joyful feeling, he also communicates his feeling of distance from his own time. This is the vertical dimension of the mood. Far from representing a diminishment, he thus means to suggest that the purification of feeling leads to a heightening of feeling and to a feeling of greater power. Nietzsche simply would have the reader trade the feeling of being in contact with a higher world for the vision of a Daybreak and the "high" mood that this vision opens up.

When Nietzsche writes about higher states of being it is not simply the curiosity of the psychologist that we witness, since his words are meant to allow the reader to enter into a mood in which he understands the joy of the philosophical life and is encouraged to strive for a desirable future. The future, however, is open. Nietzsche does not seem to write from a special position of authority, from the perspective of one who has attained a higher state of being, but rather from the point of view of one who himself is striving higher, and who has perhaps caught a glimpse of a novel culture and had a foretaste of future moods. Further support for this conclusion is found in a letter to Köselitz from the end of August 1881, in which Nietzsche explicitly identifies $D$, his latest work, as containing numerous examples of indirect persuasion [exhortatio indirecta] towards the most worthy goals that can be 
thought. ${ }^{65}$ While Nietzsche's words about "finding" this strategy at work in $D$ might suggest something less than intentional use of the strategy, one can at least surmise that he speaks as much about his own work as that of his friend's when he advises Köselitz to use all means available to the artist in order to spur his audience (i.e. those who he seeks to reach through his art) to reach for the highest goals. After all, Nietzsche writes of "our task" [unsre Aufgabe], not only of the task of his friend.

To conclude, Nietzsche is at this stage not only aware of the possibility to make creative use of mood, but he also can be said to "use mood" in his writings. Nevertheless, the readings of $H H$ and $D$ have shown that it is in general more proper to speak of Nietzsche's communication of mood than of his "use of mood". Firstly, there is an intimate relation between Nietzsche's attempts to express mood and his statements about mood. They support each other instead of conflicting. In other words, both are part of Nietzsche's communication of mood. Secondly, the word "use" is prone to be interpreted in terms of manipulation, and is therefore unsuited to describe what is going on in Nietzsche's writings. This is not to say that Nietzsche makes no such use of mood, but that in the end the idea of manipulating mood conflicts with his far stronger emphasis on independence. This potential conflict is nevertheless good to keep in mind when approaching GS, for in that work Nietzsche does not shy away from using artistic means to communicate mood.

65 "Bekennen Sie sich ungescheut zu den höchsten Absichten! Menschen wie Sie müssen ihre Worte voranwerfen und sie durch ihre Thaten einzuholen wissen (selbst ich habe mir bisher erlaubt nach dieser Praxis zu leben) Benutzen Sie alle Freiheiten, die man dem Künstler allein noch zugesteht und bedenken Sie wohl: unsre Aufgabe ist unter allen Umständen anzutreiben, 'dorthin' zu treiben - gleichgültig beinahe, ob wir selber dorthin gelangen! (Die exhortatio indirecta finde ich zum Erstaunen oft in meinem letzten Buche z.B. in dem Abschnitte $§ 542$ 'Der Philosoph und das Alter' - die direkte Ermahnung und Anreizung hat dagegen etwas so Altkluges.)” (KGB III/1, Bf. 143) 